\title{
Bioavailable atmospheric phosphorous supply to the global ocean: a 3-D global modeling study
}

\author{
Stelios Myriokefalitakis ${ }^{1}$, Athanasios Nenes ${ }^{2,3,4,5}$, Alex R. Baker ${ }^{6}$, Nikolaos Mihalopoulos ${ }^{1,5}$, and Maria Kanakidou ${ }^{1}$ \\ ${ }^{1}$ Environmental Chemical Processes Laboratory, Department of Chemistry, University of Crete, P.O. Box 2208, \\ 70013 Heraklion, Greece \\ ${ }^{2}$ Institute of Chemical Engineering Sciences (ICE-HT), FORTH, P.O. Box 1414, 26504 Patras, Greece \\ ${ }^{3}$ School of Earth and Atmospheric Sciences, Georgia Institute of Technology, 311 Ferst Drive, Atlanta, GA 30332, USA \\ ${ }^{4}$ School of Chemical and Biomolecular Engineering, Georgia Institute of Technology, 311 Ferst Drive, Atlanta, \\ GA 30332, USA \\ ${ }^{5}$ National Observatory of Athens, Institute for Environmental Research and Sustainable Development, Athens, Greece \\ ${ }^{6}$ Centre for Ocean and Atmospheric Science, School of Environmental Sciences, University of East Anglia, \\ Norwich, NR4 7TJ, UK
}

Correspondence to: Stelios Myriokefalitakis (stelios@uoc.gr) and Maria Kanakidou (mariak@chemistry.uoc.gr)

Received: 19 May 2016 - Published in Biogeosciences Discuss.: 8 June 2016

Revised: 13 November 2016 - Accepted: 23 November 2016 - Published: 15 December 2016

\begin{abstract}
The atmospheric cycle of phosphorus (P) is parameterized here in a state-of-the-art global 3-D chemistry transport model, taking into account primary emissions of total P (TP) and soluble P (DP) associated with mineral dust, combustion particles from natural and anthropogenic sources, bioaerosols, sea spray and volcanic aerosols. For the present day, global TP emissions are calculated to be roughly 1.33 $\mathrm{Tg}_{-} \mathrm{P} \mathrm{yr}^{-1}$, with the mineral sources contributing more than $80 \%$ to these emissions. The $\mathrm{P}$ solubilization from mineral dust under acidic atmospheric conditions is also parameterized in the model and is calculated to contribute about onethird (0.14 $\left.\mathrm{Tg}_{\mathrm{P}} \mathrm{P} \mathrm{yr}^{-1}\right)$ of the global DP atmospheric source. To our knowledge, a unique aspect of our global study is the explicit modeling of the evolution of phosphorus speciation in the atmosphere. The simulated present-day global annual DP deposition flux is $0.45 \mathrm{Tg}^{-\mathrm{P} \mathrm{yr}^{-1}}$ (about $40 \%$ over oceans), showing a strong spatial and temporal variability. Present-day simulations of atmospheric P aerosol concentrations and deposition fluxes are satisfactory compared with available observations, indicating however an underestimate of about $70 \%$ on current knowledge of the sources that drive the $\mathrm{P}$ atmospheric cycle. Sensitivity simulations using preindustrial (year 1850) anthropogenic and biomass burning emission scenarios showed a present-day increase of $75 \%$ in the $\mathrm{P}$ solubilization flux from mineral dust, i.e., the rate at
\end{abstract}

which $\mathrm{P}$ is converted into soluble forms, compared to preindustrial times, due to increasing atmospheric acidity over the last 150 years. Future reductions in air pollutants due to the implementation of air-quality regulations are expected to decrease the $\mathrm{P}$ solubilization flux from mineral dust by about $30 \%$ in the year 2100 compared to the present day. Considering, however, that all the $\mathrm{P}$ contained in bioaerosols is readily available for uptake by marine organisms, and also accounting for all other DP sources, a total bioavailable $\mathrm{P}$ flux of about $0.17 \mathrm{Tg}^{-} \mathrm{P} \mathrm{yr}^{-1}$ to the oceans is derived. Our calculations further show that in some regions more than half of the bioavailable $\mathrm{P}$ deposition flux to the ocean can originate from biological particles, while this contribution is found to maximize in summer when atmospheric deposition impact on the marine ecosystem is the highest due to ocean stratification. Thus, according to this global study, a largely unknown but potentially important role of terrestrial bioaerosols as suppliers of bioavailable $\mathrm{P}$ to the global ocean is also revealed. Overall, this work provides new insights to the atmospheric $P$ cycle by demonstrating that biological materials are important carriers of bioavailable $\mathrm{P}$, with very important implications for past and future responses of marine ecosystems to global change. 


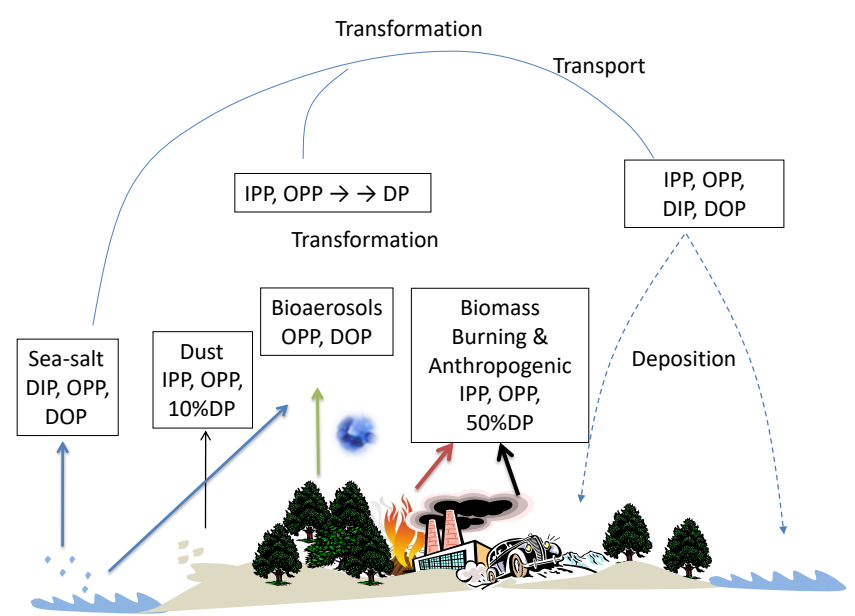

Figure 1. Simplified illustration of the atmospheric $\mathrm{P}$ cycle showing the various sources of particulate inorganic and organic P (IPP, OPP) and their soluble forms (DIP and DOP), the transformation of $\mathrm{PP}$ to DP during atmospheric transport and the deposition of $\mathrm{P}$ to the land and to the ocean. Emissions fractions among atmospheric $\mathrm{P}$ forms are those used as input in the TM4-ECPL model.

\section{Introduction}

Phosphorus $(\mathrm{P})$ is a ubiquitous element found in amino acids, in proteins and as an integral part of organisms, together with nitrogen $(\mathrm{N})$ and iron $(\mathrm{Fe})$. It is an essential nutrient that can limit primary production and nitrogen fixation in aquatic environments and thus significantly influence carbon storage (Elser et al., 2007). Reviewing experimental data, Moore et al. (2013) proposed two broad regimes of phytoplankton nutrient limitation in the modern upper ocean: (1) Nlimited regimes in most of the low-latitude oceanic surface and (2) Fe-limited regimes where subsurface nutrient supply is enhanced (while P may co-limit primary productivity). Moutin et al. (2008) pointed out the potential importance of phosphate for $\mathrm{N}_{2}$ fixation in particular in the southeast Pacific under high temperature conditions and $\mathrm{Fe}$ availability, which are favorable for the presence of $\mathrm{N}_{2}$-fixing organisms (like Trichodesmium spp.) that potentially counteract the $\mathrm{N}$ limitation (Deutsch et al., 2007). However, in some regions like the Mediterranean, primary productivity is found to be limited by $\mathrm{P}$ availability to the marine ecosystems (Krom et al., 2005). Furthermore, Brahney et al. (2015) and Du et al. (2016) found that human-driven imbalanced atmospheric deposition of $\mathrm{N}$ and $\mathrm{P}$ might have induced or will induce $\mathrm{P}$ limitation to the ecosystems (global alpine lakes and large areas of China's forests, respectively).

The two external-to-the-ocean sources of nutrients are the atmosphere and rivers. Depending on these inputs and marine dynamics, different nutrients can limit the marine primary productivity. Riverine inputs of nutrients to the marine ecosystem are important for coastal regions, while the atmospheric deposition of nutrients is a more significant source to the open ocean (Jickells et al., 2005; Duce et al., 2008; Mahowald et al., 2008). In contrast to the atmospheric reactive $\mathrm{N}$ pool, the atmospheric soluble $\mathrm{P}$ pool is less studied and remains highly uncertain. Okin et al. (2011) evaluated the impact of $\mathrm{Fe}$ and $\mathrm{P}$ atmospheric deposition to the ocean in increasing $\mathrm{N}_{2}$ fixation and found that $\mathrm{Fe}$ deposition is more important than $\mathrm{P}$ deposition in supporting $\mathrm{N}_{2}$ fixation, while they pointed out the large uncertainty in the bioavailability of atmospherically deposited P. Benitez-Nelson's (2000) review discussed the importance of discrete pulses of $\mathrm{P}$ input to the oligotrophic seas that have been found to increase the phytoplankton biomass over short timescales. They also estimated that atmospheric $\mathrm{P}$ deposition could be underestimated by as much as $50 \%$, when neglecting the $\mathrm{P}$ fraction that is soluble under acidic and high temperature conditions.

In marine ecosystems, the bioavailability of $\mathrm{P}$ is found to depend significantly on its degree of solubility (Anderson et al., 2010). Experimentally, bioavailable P is usually considered to be the "filterable" reactive or total reactive $\mathrm{P}$ that passes through a $0.45 \mu \mathrm{m}$ membrane (Maher and Woo, 1998 and references therein). Although marine organisms, such as cyanobacteria, have evolved ways to acquire $\mathrm{P}$ from mineral sources under P-limited conditions (Schaperdoth et al., 2007), phosphate is considered as the most bioavailable form of P (e.g., Björkman and Karl, 2003). Experiments have also shown that human-produced P-containing organics, such as organophosphorus pesticide breakdown products, can also be utilized by bacteria (Cook et al., 1978). Moreover, aerosol samples originating from combustion $\mathrm{P}$ sources were found to be more soluble and possibly more bioavailable than those from mineral sources (Anderson et al., 2010).

Atmospheric P has a variety of sources (Fig. 1), including mineral dust, combustion products of natural and anthropogenic origin, agricultural activities (fertilizers and insecticides), bioaerosols, volcanic emissions, sea spray and phosphine from freshwater wetlands (Mahowald et al., 2008; Tipping et al., 2014; Wang et al., 2014; Brahney et al., 2015). The total P (hereafter TP) found in natural waters can be grouped in two major forms (Maher and Woo, 1998): (1) the particulate $\mathrm{P}(\mathrm{PP})$ and (2) the soluble $\mathrm{P}$, often termed dissolved P (DP). The PP mainly originates from mineral material (e.g., hydroxyapatite, brushite, fluorapatite, variscite, strengite and wavellite) as well as $\mathrm{P}$ absorbed to mixed phases (e.g., clay $\mathrm{P}$, clay-organic $\mathrm{P}$ and metal hydroxide $\mathrm{P}$ ). The DP, on the other hand, includes orthophosphates (i.e., $\mathrm{H}_{2} \mathrm{PO}_{4}^{-}, \mathrm{HPO}_{4}^{2-}, \mathrm{PO}_{4}^{3-}$; hereafter referred to as $\left.\mathrm{PO}_{4}\right)$ and inorganic condensed $\mathrm{P}$ (pyro-, meta- and polyphosphates). However, both PP and DP can also contain organic P (OP) of both natural and anthropogenic origin. Naturally emitted OP can be sugar P, inositol P, phospholipids, phosphoproteins and phosphoamides mainly associated with plants, animal and bacterial cellular materials (Maher and Woo, 1998), commonly present in atmospheric aerosols of biological origin. In addition, orthophosphate monoesters are known products of ribonucleic acid (RNA) and lipid degradation that 
dominate the OP pool in the marine environment, which also contains orthophosphate diesters and phosphonates (Paytan et al., 2003).

Mineral dust has been estimated to be the largest externalto-the-ocean source of bioavailable P (Mahowald et al., 2008). These authors estimated a global $P$ mineral source of $1.15 \mathrm{Tg}^{\mathrm{P}} \mathrm{yr}^{-1}$ by taking into account a typical observed $\mathrm{P}$ fraction of $720 \mathrm{ppm}$ in dust emissions. They also applied a constant solubility fraction of $10 \%$ on the dust mineral source, based on the observations of Baker et al. (2006a, b) for Saharan P-containing aerosols over the Atlantic Ocean, in order to estimate the soluble $\mathrm{P}$ source associated with mineral dust. Recently published aerosol and deposition observations of African dust in Miami and Barbados (Zamora et al., 2013) suggest a total $P$ content of about $880 \mathrm{ppm}$, which is in the range of $\mathrm{P}$ fraction in dust from earlier studies (roughly 700-1090 ppm, as reviewed by Mahowald et al., 2008). Furthermore, based on OP : OC atomic ratios of 0.001-0.009 observed in several types of soils, Kanakidou et al. (2012) calculated that about $0.03 \mathrm{Tg}_{\mathrm{Pyr}} \mathrm{Pr}^{-1}$ of OP $(10 \%$ of which is soluble) is also emitted together with soil dust in the global atmosphere.

P-containing dust solubilization in deliquesced mineral dust aerosols is expected to significantly contribute to the soluble inorganic forms of P (DIP) in the atmosphere. Nenes et al. (2011) suggested that dissolution of apatite minerals (i.e., $\left.\mathrm{Ca}_{5}\left(\mathrm{PO}_{4}\right)_{3}(\mathrm{OH}, \mathrm{F}, \mathrm{Cl})\right)$ under acidic conditions can explain the observed DIP levels over the eastern Mediterranean, a characteristic region where Saharan dust can interact with polluted air masses from Europe and the Middle East. Under acidic atmospheric conditions, $\mathrm{H}^{+}$can react with the $\mathrm{PO}_{4}$ and the $\mathrm{OH}$ or $\mathrm{F}$ groups in the crystal surface, weakening the $\mathrm{Ca}^{2+}$ bonds and thus causing phosphate to be mobilized from the crystal surface (Christoffersen and Christoffersen, 1981). Hence, mineral dust acid dissolution under polluted conditions can potentially increase the bioavailable $\mathrm{P}$ supply into oceanic regions and further stimulate the net primary production of marine ecosystems (Nenes et al., 2011).

Primary $\mathrm{P}$ sources from combustion processes of anthropogenic and biomass burning origin are estimated to contribute significantly to global $\mathrm{P}$ fluxes in the atmosphere (Mahowald et al., 2008; Tipping et al., 2014; Wang et al., 2014; Brahney et al., 2015). However, the estimates of global strength of the primary $\mathrm{P}$ combustion source vary by about an order of magnitude on the global scale, due to the consideration of different forms of the emitted $\mathrm{P}$ (i.e., residual or $\mathrm{P}$-containing ash, gaseous or particulate $\mathrm{P}$ produced during combustion processes; Wang et al., 2014) and different size distributions in the emitted $\mathrm{P}$-containing particulate matter. Mahowald et al. (2008) used observed mass ratios of $\mathrm{P}$ to black carbon $(\mathrm{BC})$ for fine $(<2 \mu \mathrm{m})$ and coarse $(2 \mu \mathrm{m} \leq$ mean particle diameter $<10 \mu \mathrm{m}$ ) particles (Mahowald et al., 2005) and calculated emission fluxes from biomass burning and anthropogenic fuel (i.e., fossil fuel and biofuel) combustion of 0.03 and $0.05 \mathrm{Tg}-\mathrm{P} \mathrm{yr}^{-1}$, respectively. Tipping et al. (2014) estimated a global atmospheric P emission flux of 3.7 Tg-P $\mathrm{yr}^{-1}$ by combining observed deposition rates over land together with modeled deposition rates over the ocean. This emission flux also accounts for $\mathrm{P}$ deposition fluxes of larger particles (i.e., primary biological material in the aerosol mode $>10 \mu \mathrm{m}$ ) that are mainly deposited very close to their source region and thus not long-range transported. On the other hand, Wang et al. (2014), by assuming that combustion processes emit significant amounts of $\mathrm{P}$ as large particles $>10 \mu \mathrm{m}$ (hereafter as super-coarse particles), calculated that $\mathrm{P}$ emissions from biomass burning and anthropogenic combustion processes can contribute about 0.7 and $1.8 \mathrm{Tg}_{\mathrm{P}} \mathrm{Pr}^{-1}$, respectively. In contrast to that study, which was more focused on the impact of anthropogenic combustion on the global P source, Brahney et al. (2015) extended the methodology of Mahowald et al. (2008) in a more explicit aerosol size manner by taking into account also the naturally emitted super-coarse P-containing particles (i.e., dust, primary biological material and sea salt). Brahney et al. (2015) showed that considering this super-coarse fraction as an additional $\mathrm{P}$ source, the estimated deposition fluxes close to the source areas where large particles are emitted (e.g., Tipping et al., 2014) can be significantly improved.

The sea surface microlayer can also act as an atmospheric source of $P$ in the marine environment (Graham et al., 1979). Correlations between sea-salt fluxes and seawater P concentrations revealed a 10 - to 200 -fold enrichment of $\mathrm{P}$ content in sea-salt particles compared to seawater Na concentrations (Graham and Duce, 1979; Graham et al., 1979). However, this enrichment was found to decrease with increasing wind velocity, introducing significant uncertainty in the strength of the oceanic flux of P on a global scale. The Vet et al. (2014) review of deposition observations pointed out that sea spray may be a weak contributor to atmospheric P. Mahowald et al. (2008), taking into account a constant $\mathrm{Na}$ concentration in seawater of $10.781 \mathrm{~g}-\mathrm{Na} \mathrm{kg-water}{ }^{-1}$ and surface seawater phosphate concentrations from the NOAA Data Center, calculated a global annual flux of soluble P of 0.0049 Tg-P yr ${ }^{-1}$ (accounting for particles up to $10 \mu \mathrm{m}$ in diameter; i.e., $\mathrm{PM}_{10}$ ). Wang et al. (2014) used a total oceanic emission P flux of $0.16 \mathrm{Tg}_{-} \mathrm{P} \mathrm{yr}^{-1}$ that was calculated as the average of earlier estimates (ranging from 0.005-0.33). Additionally, Paytan et al. (2003) found that OP in the seawater particulate matter can be up to $80 \%$ of total P. Based on an OP / Na mass ratio of $0.02 \%$ as observed by Graham and Duce (1979), Kanakidou et al. (2012) estimated that the surface global ocean may also emit $0.19-0.80 \mathrm{Tg}^{-\mathrm{P} \mathrm{yr}^{-1}}$ in the form of OP.

Bioaerosols are $\mathrm{P}$ carriers (Mahowald et al., 2008) that can significantly contribute to the OP budget in the atmosphere (Kanakidou et al., 2012). These primary biological aerosol particles (hereafter PBAPs) usually range from $10 \mathrm{~nm}$ to roughly $100 \mu \mathrm{m}$ in diameter and, depending on their size, origin and type, can be transported over long distances. PBAPs can be either alive, dead, dormant (e.g., bacteria, viruses and fungi spores) or products released from living organisms 
such as pollen (Ariya et al., 2009). Mahowald et al. (2008) calculated that PBAPs contribute $0.165 \mathrm{Tg}^{-\mathrm{P} \mathrm{yr}^{-1}}$ to global DP emissions, while Kanakidou et al. (2012), based on organic carbon (OC) estimates of PBAP emissions and by using a OP : OC atomic ratio of 0.001 , calculated that PBAPs contribute about $0.13 \mathrm{Tg}-\mathrm{P} \mathrm{yr}^{-1}$ to global OP emissions. Large uncertainties, however, are associated with this estimate since it relies on the applied OP: OC ratios of PBAPs that have been observed to range over 2 orders of magnitude from about 0.0002 up to 0.02 (Kanakidou et al., 2012 and references therein) and on the simplified approximation of the density $\left(1-1.2 \mathrm{~g} \mathrm{~cm}^{-3}\right)$ used for the conversion of the PBAP number fluxes to mass units (Burrows et al., 2009a, b). Mahowald et al. (2008) and Kanakidou et al. (2012) assumed half of the PBAP source to be hydrophilic, while Heald and Spracklen (2009) assumed all PBAPs to be totally hydrophilic particles using an OM : OC ratio of 2.6 that is based on observations of fungal spores as proposed by Bauer et al. (2008). However, bacteria (e.g., P. syringae) are considered as rather insoluble bioaerosols, in contrast to the water-soluble fractions of highly polar sugars (fructose, glucose, sucrose, trehalose) and sugar alcohols (arabitol, inositol, mannitol), mainly contained in pollen grains and fungi spores (Ariya et al., 2009). Ageing during atmospheric transport is also expected to increase bioaerosols' solubility, converting a fraction of their insoluble OP content to soluble OP (DOP) due to the uptake of oxidants and the formation of larger chains of soluble multifunctional groups (Ariya et al., 2009). Regardless of bioaerosols being hydrophilic or not, because they consist of biological material, they are expected to be bioavailable (Bjórkman and Karl, 1994). The degree of hydrophilicity therefore is more important for determining the relative importance of dry and wet deposition during their supply to the oceans.

In the present study, the 3-D chemical transport global model TM4-ECPL is used to integrate current knowledge on the atmospheric $\mathrm{P}$ cycle and simulate the atmospheric concentrations and deposition fluxes of $\mathrm{P}$ over land and oceans, driven by mineral, natural and combustion $\mathrm{P}$ emissions. To our knowledge, this is the first study that accounts for both inorganic and organic forms of $\mathrm{P}$ and their evolution in the atmosphere. Furthermore, we also present the first global estimate of the $\mathrm{PO}_{4}$ flux due to the acid solubilization of dust particles. The model description and the parameterization of atmospheric acidity impact on the $\mathrm{P}$ solubilization from mineral dust aerosol in atmospheric water, together with the OP atmospheric ageing contribution to the DP global budgets are presented in Sect. 2. The calculated TP and DP global atmospheric concentrations are shown and compared to observations in Sect. 3. In Sect. 4, the importance of present-day air pollutants on DP atmospheric deposition is investigated based on simulations using past and future anthropogenic and biomass burning emission scenarios. The contribution of bioaerosols to the bioavailable $\mathrm{P}$ atmospheric deposition and implications of the findings concerning the biogeochem- istry of marine ecosystems are also discussed (Sect. 4). Overall, the impacts of human-driven changes on the calculated DP deposition fluxes to the global ocean are summarized in Sect. 5.

\section{Model description}

The TM4-ECPL global chemistry transport model (Myriokefalitakis et al., 2015) simulates the oxidant chemistry accounting for non-methane volatile organics and all major aerosol components, including secondary inorganic aerosols like sulfate $\left(\mathrm{SO}_{4}^{2-}\right)$, nitrate $\left(\mathrm{NO}_{3}^{-}\right)$and ammonium $\left(\mathrm{NH}_{4}^{+}\right)$calculated using the ISORROPIA II thermodynamic model (Fountoukis and Nenes, 2007) and secondary organic aerosols (Tsigaridis and Kanakidou, 2007; Tsigaridis et al., 2014). The atmospheric cycles of Fe and N in TM4-ECPL have been parameterized and evaluated in Myriokefalitakis et al. (2015) and Kanakidou et al. (2016), respectively, while uncertainties in the computed atmospheric composition associated with different emission parameterizations have been calculated in Daskalakis et al. (2015). The model's ability to reproduce distributions of organic aerosols (Tsigaridis et al., 2014) and tropospheric ozone, ozone's precursors and aerosols have been also evaluated against satellite and in situ observations (Eckhardt et al., 2015; Stohl et al., 2015; Quennehen et al., 2016; Myriokefalitakis et al., 2016).

TM4-ECPL is driven by the ECMWF (European Centre for Medium-Range Weather Forecasts) Interim Reanalysis project (ERA-Interim) meteorology (Dee et al., 2011). The current model configuration has a horizontal resolution of $3^{\circ}$ in longitude by $2^{\circ}$ in latitude and 34 hybrid layers in the vertical, from the surface up to $0.1 \mathrm{hPa}$, with a model time step of 30 min. TM4-ECPL uses modal size (lognormal) distributions to describe the evolution of fine and coarse aerosols in the atmosphere. In the model, phosphorus is parameterized using $32 \mathrm{P}$-containing aerosol tracers of different sizes and solubilities. In TM4-ECPL, different sources emit Pcontaining aerosols of different sizes represented by lognormal distributions as outlined in Sect. 2.1. For each aerosol mode and source (Fig. 1), the model accounts for total P, phosphate, insoluble and soluble OP. For the dust source, it also accounts for the two P-containing minerals (fluorapatite and hydroxyapatite) as further described in Sect. 2.1.1. These are individually transported, aged and deposited in the atmosphere. The "dry" aerosol hygroscopic growth in the model is treated as a function of ambient relative humidity and the composition of soluble aerosol components based on experimental work by Gerber (1985) and this uptake of water on aerosols changes the particle size. In addition, during atmospheric transport, there are major changes in the size distribution of aerosols as a consequence of the removal of larger particles due to gravitational settling. The P-containing aerosols follow the same parameterizations, hygroscopic growth and 
removal processes that affect the mass median radius (i.e., size).

TM4-ECPL uses anthropogenic (including ship and aircraft) emissions and biomass burning emissions from the historical Atmospheric Chemistry and Climate Model Intercomparison Project (ACCMIP) database (Lamarque et al., 2013) for the years 1850 (hereafter PAST), 1999 and 2000 from the Representative Concentration Pathways 6.0 (RCP 6.0) emission scenario (van Vuuren et al., 2011) for the years 2001 to 2010 (year 2008 is hereafter called PRESENT) and for the year 2100 (hereafter FUTURE) that have been used for the sensitivity simulations. Details on anthropogenic and natural emissions used for this work are provided in Myriokefalitakis et al. (2015) with the exception of mineral dust that, for the present study, is calculated online as in van Noije et al. (2014), based on the dust source parameterization of Tegen et al. (2002). The three base simulations (PAST, PRESENT and FUTURE) have been performed with meteorology for the year 2008. Note, however, that we have extended the present-day simulation to the 11-year period from 2000 to 2010 with a spin-up time of 1 year (i.e., with 1999 meteorology and emissions), to cover the majority of the dates of the available atmospheric observations used for model evaluation (see Sects. 2.4 and 3.2).

\subsection{Phosphorus emissions}

\subsubsection{Phosphorus emissions from mineral dust}

Apatite is the most abundant primary natural source of $\mathrm{P}$ in soils (Newman, 1995), compared to other low solubility $\mathrm{P}$ forms such as secondary metal phosphate precipitates and organic phosphate. For the present study, apatite is assumed to be the only mineral in dust that contains $\mathrm{P}$. The spatially distributed fraction of $\mathrm{P}$ in soils $\left(f_{\mathrm{P}}\right)$ from the global soil mineralogy dataset developed by Nickovic et al. (2012) is used to calculate the inorganic P-containing mineral (i.e., apatite) emissions as

$E_{\mathrm{P}}=F_{880} \cdot f_{\mathrm{P}} \cdot E_{\mathrm{Du}}$,

where $E_{\mathrm{Du}}$ is the online calculated dust emissions in the model, $F_{880}$ is a factor applied to adjust the $\mathrm{P}$ emissions to the global mean $\mathrm{P}$ content of mineral dust in the model domain of 880 ppm per weight as observed by Zamora et al. (2013) and $E_{\mathrm{P}}$ are the resulting inorganic $\mathrm{P}$ emissions from mineral dust. P-containing minerals associated with dust particles are emitted in the fine and coarse mode with mass median radii (lognormal standard deviation) of 0.34 (1.59) and $1.75 \mu \mathrm{m}$ (2.00), respectively. The P-containing dust aerosol emissions are treated as a lognormal distribution with a dry mass median radius and sigma same as that of dust particles. Particle sizes are changing due to hygroscopic growth as a function of ambient relative humidity and the composition of soluble aerosol components (Gerber, 1985). Note, however, that no coagulation among different dust modes is considered for the current study.

Although in most relevant modeling studies airborne $\mathrm{P}$ containing dust particle emissions are assumed to have an average P content of 720 ppm (Mahowald et al., 2008; Wang et al., 2014; Brahney et al., 2015) in the atmosphere due to transport, ageing and deposition processes; the overall mineralogy may change the chemical composition and size of the dust aerosol population. In a recent iron modeling study (Perlwitz et al., 2015), however, a significant effort has been made to model the mineral composition of dust considering the differences from the original soil composition. Perlwitz et al. (2015) have found a significant overestimate (a factor of 10-30) mainly in the fine aerosol emissions that are the smallest part of dust emissions (e.g., about $7 \%$ of the total emissions in our model) and an underestimate in the larger particle emissions both for total dust and for individual minerals when the mineralogy of dust aerosol is assumed to be the same as that of the soil. However, for the present study, we did not account for different $\mathrm{P}$ content for dust particles in the fine and the coarse mode, since the global soil mineralogy dataset used by Nickovic et al. (2012) does not provide any information of $\mathrm{P}$ content in silt and clay soil particles separately. Note also that recent studies indicate that dust super-coarse particles can be very important for the biogeochemistry over land, since they can represent the dominant fraction of dust close to source regions (Lawrence and Neff, 2009; Neff et al., 2013). The Brahney et al. (2015) modeling study that focused on the atmospheric phosphorus deposition over global alpine lakes, based on Neff et al. (2013) observations, estimated that only $10 \%$ of the mass that travels in the atmosphere is within the $<10 \mu \mathrm{m}$ size fraction. In our study, we do not account for super-coarse dust particles because due to their short atmospheric lifetime, they are emitted and deposited in the same model grid box (Brahney et al., 2015). This omission is not expected to have a significant impact on our results, since the present work is focused on the Psolubilization mechanisms occurring via atmospheric longtransport mixing and on the bioavailable $\mathrm{P}$ deposition over the marine environment.

For the year 2008, the mineral dust emissions calculated in TM4-ECPL amount to $1181 \mathrm{Tg} \mathrm{yr}^{-1}$ and the corresponding apatite emissions to $1.034 \mathrm{Tg} \mathrm{P} \mathrm{yr}^{-1}$ with $10 \%$ of it $\left(0.103 \mathrm{Tg}_{\mathrm{P}} \mathrm{yr}^{-1}\right)$ in the soluble form (Table 1$)$. The soluble fraction used in our model is based on the measurements of leachable inorganic phosphorus (LIP) for Saharan soil dust, as presented by Nenes et al. (2011). These authors found that LIP represented up to $10 \%$ of total inorganic P in Saharan soil samples and dry fallout collected during Sahara dust storms before acid treatment. Moreover, Yang et al. (2013) estimated the labile inorganic $\mathrm{P}$ in the top soil on the global scale at about 3.6 Pg-P, which corresponds to about $10 \%$ of the estimates of total soil $\mathrm{P}$ on the global scale $30.6-40.6 \mathrm{Pg}$ P (Smil, 2000; Wang et al., 2010; Yang et al., 2013). To further investigate uncertainties associated with the soluble frac- 
Table 1. Emissions of TP and DP (in Tg-P yr ${ }^{-1}$ ) taken into account in the TM4-ECPL model for PAST, PRESENT and FUTURE simulations. In parenthesis, the average values of TP and DP emissions for the years 2000-2010 are also provided.

\begin{tabular}{rrrrrrrrr}
\hline \multicolumn{2}{l}{ TM4-ECPL } & $\begin{array}{r}\text { Biomass } \\
\text { burning }\end{array}$ & $\begin{array}{r}\text { Anthropogenic } \\
\text { combustion }\end{array}$ & Volcanoes & PBAPs & Sea spray & Soils & Total \\
\hline TP & PAST & 0.014 & 0.008 & & & & & 1.289 \\
& PRESENT & 0.018 & 0.043 & 0.006 & 0.156 & 0.008 & 1.097 & 1.328 \\
& & $(0.018)$ & $(0.042)$ & $(0.006)$ & $(0.156)$ & $(0.008)$ & $(1.095)$ & $(1.326)$ \\
& FUTURE & 0.022 & 0.009 & & & & & 1.298 \\
\hline \multirow{2}{*}{ DP } & PAST & 0.007 & 0.004 & & & & 0.254 \\
& PRESENT & 0.009 & 0.021 & 0.006 & 0.123 & 0.008 & 0.106 & 0.272 \\
& & $(0.009)$ & $(0.021)$ & $(0.006)$ & $(0.123)$ & $(0.007)$ & $(0.105)$ & $(0.271)$ \\
& FUTURE & 0.011 & 0.004 & & & & 0.258 \\
\hline
\end{tabular}

tion of P-containing dust aerosol emissions in our model, an additional simulation has been performed neglecting any soluble fraction on initial emissions.

In addition to the desert dust inorganic $\mathrm{P}$ source, we account for the OP present in soil's organic matter, following the method developed by Kanakidou et al. (2012, and references therein). Thus, using a mean OP : OC molar ratio of 0.005 , a mean OM content of soil dust of $0.25 \%$ and an OM : OC molar ratio of 1.76 , we evaluate the dust source of OP here at $0.022 \mathrm{Tg}_{-} \mathrm{P} \mathrm{yr}^{-1}$ for the year 2008. This flux is in good agreement with the $0.03 \mathrm{Tg}-\mathrm{P} \mathrm{yr}^{-1}$ calculated for 2005 by Kanakidou et al. (2012) using the same methodology but with the AEROCOM database for dust emission fluxes (Dentener et al., 2006). Note that similarly to that earlier study, a solubility of $10 \%$ is applied here to the OP dust emissions.

\subsubsection{Phosphorus emissions from combustion sources}

For the present study, the $\mathrm{P} / \mathrm{BC}$ mass ratios of combustion sources as estimated by Mahowald et al. (2008; i.e., 0.0029 for fine aerosols and 0.02 for coarse aerosols) are applied to the inventories of monthly BC emissions of anthropogenic (i.e., for fossil fuel, coal, waste and biofuel) and biomass burning origin, as provided by the historical ACCMIP database for 1850 and from the RCP 6.0 for 2008 and 2100 . In the model, a number mode radius of $0.04 \mu \mathrm{m}$ and a lognormal standard deviation of 1.8 are assumed for fine $\mathrm{P}$ emissions, while for coarse $\mathrm{P}$ a number mode radius of $0.5 \mu \mathrm{m}$ and lognormal standard deviation of 2.00 are used as proposed for combustion aerosols by Dentener et al. (2006). $\mathrm{BC}$ emissions from anthropogenic combustion in the coarse mode are assumed to be $25 \%$ of those in the fine mode (Jacobson and Streets, 2009), while biomass burning emissions in the coarse mode are assumed equal to $20 \%$ of those of fine aerosols (Mahowald et al., 2008). Thus, the computed anthropogenic combustion and biomass burning annual mean sources of TP are calculated to be 0.043 (by about $70 \%$ in the coarse mode) and $0.018 \mathrm{Tg}^{-\mathrm{P} \mathrm{yr}^{-1}}$ (by about $66 \%$ in the coarse mode), respectively, all corresponding to the year 2008. Despite the different emission databases and the aerosol size parameterization, the computed present-day TP sources for the year 2008 are comparable to those of Mahowald et al. (2008) for the year 2000 (i.e., 0.045 and $0.025 \mathrm{Tg}^{-} \mathrm{yr}^{-1}$ for anthropogenic combustion and biomass burning, respectively). PAST, PRESENT and FUTURE combustion emissions calculated for this study based on the ACCMIP and RCP 6.0 database are presented in Table 1.

Half of TP emissions from combustion sources are considered to be in the form of OP following the approach of Kanakidou et al. (2012). All P-containing particles from combustion emissions are initially treated here as $50 \%$ soluble (Mahowald et al., 2008). The insoluble fraction of OP associated with combustion emissions can be further converted to soluble OP (DOP) during atmospheric ageing, using the ageing parameterization for primary hydrophobic organic aerosols in the model (Tsigaridis and Kanakidou, 2003; Tsigaridis et al., 2006), but for the respective size and lognormal distribution of OP aerosols (with the larger particles experiencing the smallest conversion rates).

To further investigate uncertainties in the $\mathrm{P}$ combustion emissions in our model, an additional present-day simulation was performed taking into account the total (bulk) mass of anthropogenic combustion and biomass burning P emissions, as developed by Wang et al. (2014; R. Wang, personal communication, 2016). According to that database, global anthropogenic emissions from fossil fuels, biofuels and deforestation fires amount to $1.079 \mathrm{Tg}_{-} \mathrm{P} \mathrm{yr}^{-1}$ and natural fire emissions are equal to $0.808 \mathrm{Tg}^{-} \mathrm{P} \mathrm{yr}^{-1}$. For this sensitivity simulation, we apply the size distribution as described in Wang et al. (2014); i.e., by dividing total emissions into three modes - one fine ( $2 \%$ of P) and two coarse modes ( 25 and $73 \%$ of P) - with mass mode dry diameters of $0.14,2.5$ and $10 \mu \mathrm{m}$ and lognormal standard deviations of 1.59 and 2.00 for fine and coarse modes, respectively. 


\subsubsection{Phosphorus emissions from primary biological aerosol particles}

Three types of P-containing PBAPs are considered for the present study: bacteria (BCT), fungal spores (FNG) and pollen grains (PLN). PBAPs from other sources, such as insect fragments and plant debris (e.g., Després et al., 2012), are however neglected in the present study. Omission of these super-coarse particles is expected to lead to an underestimate in the PBAP contribution to $\mathrm{P}$ deposition over land that requires evaluation with targeted observations. The BCT fluxes are parameterized based on the Burrows et al. (2009b) best-fit estimates for particles of $1 \mu \mathrm{m}$ diameter flux rates $(f)$ and for six different ecosystems: coastal: 900; crops: 704; grassland: 648; land ice: 7.7; shrubs: 502; and wetlands: $196 \mathrm{~m}^{-2} \mathrm{~s}^{-1}$. For the present study, the Olson Global Ecosystem Database (Olson, 1992), originally available for 74 different land types on a spatial scale of $0.5^{\circ} \times 0.5^{\circ}$, is lumped into 10 ecosystem groups as proposed by Burrows et al. (2009). The total BCT flux $\left(F_{\mathrm{BCT}} ; \mathrm{s}^{-1}\right)$ in the model is calculated based on the aforementioned fluxes $\left(f_{i} ; \mathrm{m}^{-2} \mathrm{~s}^{-1}\right)$ per ecosystem $(i)$, weighted by the respective ecosystem area fraction in the model grid box $\left(a_{i} ; \mathrm{m}^{2}\right)$ as

$F_{\mathrm{BCT}}=\sum_{i=1}^{6} a_{i} \cdot f_{i}$.

Heald and Spracklen (2009) proposed that FNG fluxes linearly depend on the leaf area index $\left(\mathrm{LAI} ; \mathrm{m}^{2} \mathrm{~m}^{-2}\right)$ and the specific humidity $\left(q ; \mathrm{kg} \mathrm{kg}^{-1}\right)$, based on near-surface mannitol observations. For the present study, however, we use a recently published emission parameterization proposed by Hummel et al. (2015), as derived based on fluorescent biological aerosol particles field measurements at various locations across Europe and for spores with a mean dry diameter of $3 \mu \mathrm{m}$ (Eq. 3):

$F_{\mathrm{FNG}}=20.426 \cdot(T-275.82 K)+3.93 \cdot 10^{4} \cdot q \cdot \mathrm{LAI}$.

In the TM4-ECPL, that parameterization (Eq. 3) is used to calculate FNG emissions online, using monthly averaged LAI distributions and 3-hourly averaged specific humidity $(q)$ and temperature $(T)$ data, as provided by ERA-Interim.

PLN emissions maximize when plant surfaces are dry and are under high turbulence during the morning hours and during spring months (Jacobson and Streets, 2009). Hoose et al. (2010) parameterized the pollen flux rate as linearly dependent on LAI, assuming particles with a mean dry diameter of $30 \mu \mathrm{m}$, by simplifying the more sophisticated parameterization developed by Jacobson and Streets (2009) for a global model. Here, we use the Jacobson and Streets (2009) pollen parameterization (particle mean dry diameter of $30 \mu \mathrm{m}$ ) with the pollen flux $\left(F_{\mathrm{PLN}} ; \mathrm{s}^{-1}\right)$ calculated by the following equation:

$F_{\mathrm{PLN}}=f_{\mathrm{PLN}} \cdot \mathrm{LAI} \cdot R_{\mathrm{month}} \cdot R_{\mathrm{hour}}$, where $f_{\mathrm{PLN}}=0.5 \mathrm{~m}^{-2} \mathrm{~s}^{-1}$, the factor $R_{\mathrm{month}}$ accounts for the seasonal and $R_{\text {hour }}$ the hourly pollen flux variation.

PBAPs are assumed here to be monodisperse spherical particles (Hoose et al., 2010; Hummel et al., 2015) of $1 \mathrm{~g} \mathrm{~cm}^{-3}$ density (Sesartic and Dallafior, 2011) with an organic matter to organic carbon (OM:OC) ratio set equal to 2.6 (i.e., that of mannitol) corresponding to a molecular weight equal to $31 \mathrm{~g} \mathrm{~mol}^{-1}$, as suggested by Heald and Spracklen (2009). According to our model estimates, roughly $60 \mathrm{Tg}^{-\mathrm{C} \mathrm{yr}^{-1}}$ are emitted as PBAPs. Bacterial emissions are assumed to be completely insoluble (Ariya et al., 2009), fungal spores are emitted as $50 \%$ soluble aerosols (Mahowald et al., 2008; Kanakidou et al., 2012), while pollen is emitted as totally soluble aerosols (Hoose et al., 2010). A constant mean $\mathrm{P}: \mathrm{C}$ atomic ratio of 0.001 is used for PBAPs, as suggested by Kanakidou et al. (2012) and all P is assumed in the form of OP. Based on the above parameterizations, the model calculates an OP emission flux associated with a PBAP value equal to $0.156 \mathrm{Tg}_{-} \mathrm{P} \mathrm{yr}^{-1}$, of which $0.123 \mathrm{Tg}^{-\mathrm{P} \mathrm{yr}^{-1}}$ (about $80 \%$ ) is considered to be in the form of DOP (Table 1). However, because PBAPs consist of biological material, they are considered here to be bioavailable for marine ecosystems, as further discussed in Sect. 4.1 and 4.2. In addition, in TM4ECPL, upon emission, the insoluble fraction of PBAPs becomes progressively soluble due to atmospheric ageing. This process that has been seen to occur, for instance, by degradation of RNA (Paytan et al., 2003), in TM4-ECPL is parameterized based on oxidant levels as for all organic aerosols (Tsigaridis and Kanakidou, 2003; Tsigaridis et al., 2006).

\subsubsection{Phosphorus emissions from sea spray}

Oceanic $\mathrm{P}$ emissions associated with sea spray are computed online here based on a sea-salt emission flux parameterization of Vignati et al. (2010), accounting for fine and coarse modes, with number mode dry radii of 0.09 and $0.794 \mu \mathrm{m}$, and lognormal standard deviations of 1.59 and 2.00 for accumulation and coarse particles, respectively. Sea-spray emissions are driven by the model's meteorology, and for the year 2008 , the model calculates a total of about $8284 \mathrm{Tg} \mathrm{yr}^{-1}$ of sea-salt emissions (of which $41 \mathrm{Tg} \mathrm{yr}^{-1}$ are in the fine mode). These numbers compare well with the AEROCOM recommendation of $7925 \mathrm{Tg} \mathrm{yr}^{-1}$ by Dentener et al. (2006) and are within the range of $2272-12462 \mathrm{Tg} \mathrm{yr}^{-1}$ computed by Tsigaridis et al. (2013) using several different parameterizations. Note that our sea-salt source estimation is, however, much lower than the one used in the modeling study by Wang et al. (2014; i.e., $25300 \mathrm{Tg} \mathrm{yr}^{-1}$ ), since super-coarse sea-salt particles are not considered in the current parameterization.

The oceanic P emissions in TM4-ECPL are calculated as

$E_{\mathrm{PO}_{4}}=\frac{[P] / \mathrm{MW}_{\mathrm{P}}}{[\mathrm{Na}] / \mathrm{MW}_{\mathrm{Na}}} \cdot E_{\mathrm{Na}}$,

where $[P]$ is the $\mathrm{P}$ seawater concentrations in $\mu \mathrm{M}$, $[\mathrm{Na}]$ is $\mathrm{Na}$ seawater concentration in $\mu \mathrm{M}$ and $E_{\mathrm{Na}}$ is the sea- 
salt emission flux from the ocean surface in $\mathrm{kg}-\mathrm{Na} \mathrm{m}^{-2} \mathrm{~s}^{-1}$. MW is the corresponding molecular weight of $\mathrm{P}$ and $\mathrm{Na}$, used to convert molar to mass ratios. In TM4-ECPL, seasalt particles are emitted from the ocean's surface every time step using surface wind-speed data from the ERA-Interim database (updated every $3 \mathrm{~h}$ ). Surface seawater $\mathrm{PO}_{4}$ concentrations come from the LEVITUS94 World Ocean Atlas (Conkright et al., 1994; http://iridl.ldeo.columbia.edu/ SOURCES/.LEVITUS94/.ANNUAL/.PO4/) ranging up to about $3 \mu \mathrm{M}$ of $\mathrm{PO}_{4}$ in the global ocean. Taking into account that the average $\mathrm{Na}$ concentration in seawater is about $10.781 \mathrm{~g}-\mathrm{Nakg}$-water ${ }^{-1}$, as well as an average seawater salinity of $35.5 \mathrm{~g} \mathrm{~kg}$-water ${ }^{-1}$, the spatial distribution of surface oceanic $\mathrm{Na}$ concentrations can be derived from the distribution of the surface salinity concentrations as provided by the LEVITUS94 World Ocean Atlas (Levitus et al., 1994; http://iridl.ldeo.columbia.edu/SOURCES/ .LEVITUS94/.ANNUAL/.sal/). Note that surface concentrations, both for seawater $\mathrm{PO}_{4}$ and salinity, correspond to the data available for $0 \mathrm{~m}$ depth (with the next available depth in the LEVITUS94 database at $10 \mathrm{~m}$ ).

We additionally take into account the OP oceanic emissions, as described in Kanakidou et al. (2012; see Supplement and references therein). For this, the model accounts for a mean seawater OP concentration of $0.2 \mu \mathrm{M}$ of P, based on Björkman and Karl (2003) observations. Since, to our knowledge, no spatial distribution of seawater OP concentrations is available, the monthly mean surface chlorophyll $a(\mathrm{Chl} a)$ concentrations from MODIS retrievals, used in the model to derive marine primary organic aerosol emissions (Myriokefalitakis et al., 2010), are used as a proxy to geographically distribute the mean seawater OP concentrations. Overall, the model calculates an emission flux of TP equal to $0.008 \mathrm{Tg}$ $\mathrm{P} \mathrm{yr}^{-1}$ from the global ocean (Table 1), of which $0.001 \mathrm{Tg}$ $\mathrm{P} \mathrm{yr}^{-1}$ is in the form of OP. Note that the insoluble fraction of oceanic OP in the model can be transferred to the soluble mode (DOP) due to atmospheric ageing processes. The omission of the super-coarse sea-salt aerosol might affect our estimates of P deposition to the ocean. Brahney et al. (2015) evaluated this source at $0.0046 \mathrm{Tg}_{\mathrm{P}} \mathrm{yr}^{-1}$, an amount that introduces a $3 \%$ underestimate to the present-day $\mathrm{P}$ deposition flux to the oceans calculated here.

\subsubsection{Phosphorus emissions from volcanic aerosols}

Mahowald et al. (2008) estimated that about $0.006 \mathrm{Tg}-\mathrm{P} \mathrm{yr}^{-1}$ is associated with volcanic aerosols on a global scale, based on volcanic plume observations. Although, on a global scale, volcanic ash is a small source of TP, it is found to impact, at least regionally, the ocean nutrient distributions and marine productivity (Uematsu et al., 2004; Henson et al., 2013; Olgun et al., 2013). For the present study, we applied that global annual mean volcanic flux (see also Table 1), using the distribution of sulfur volcanic emissions by Andres and Kasgnoc (1998), as updated by Dentener et al. (2006). Vol- canic phosphorus is assumed here to reside in the fine particulate mode and is treated in the model as totally soluble aerosol (i.e., DIP), as proposed by Mahowald et al. (2008). The lognormal size-distribution parameters used for volcanic $\mathrm{P}$ aerosol have a number mode radius of $0.04 \mu \mathrm{m}$ and a lognormal standard deviation of 1.8 as for sulfate fine aerosols from continuous volcanic eruptions (Dentener et al., 2006).

\subsection{Phosphorus acid-solubilization mechanism}

Phosphorus solubilization from mineral dust under acidic atmospheric conditions is assumed here to occur for the leastand the most-soluble member of apatite minerals as proposed by Nenes et al. (2011): the fluorapatite $\left(\mathrm{Ca}_{5}\left(\mathrm{PO}_{4}\right)_{3}(\mathrm{~F})\right.$; hereafter FAP) and the hydroxyapatite $\left(\mathrm{Ca}_{5}\left(\mathrm{PO}_{4}\right)_{3}(\mathrm{OH})\right.$; hereafter HAP), respectively. FAP is considered as a geologically abundant apatite, usually present in the form of igneous or sedimentary carbonate FAP (Guidry and Mackenzie, 2003). However, due to lack of information on the relative abundance and geographic distribution of FAP and HAP in soils, we assume equal mass fractions of FAP and HAP in apatitecontaining soils.

The dissolution of FAP and HAP here is treated as a kinetic process, the rate of which depends on the $\mathrm{H}^{+}$activity of atmospheric water (i.e., aerosol water and cloud droplets), the reactivity of $\mathrm{P}$ species, the ambient temperature and the degree of solution saturation. For aerosol water, the activity of $\mathrm{H}^{+}$is calculated online in the model by the thermodynamic module ISORROPIA II (Fountoukis and Nenes, 2007). For cloud water, the $\mathrm{H}^{+}$concentration is calculated by the aqueous-phase chemistry module as presented in Myriokefalitakis et al. $(2011,2015)$. The phosphate dissolution rate $(R)$, as moles of $\mathrm{HPO}_{4}^{-2}$ per second per gram of apatite, is obtained using the empirical formulation of Lasaga et al. (1994):

$R=K(T) \cdot a\left(\mathrm{H}^{+}\right)^{m} \cdot f \cdot A$,

where $K$ is the reaction constant in moles $\mathrm{m}^{-2} \mathrm{~s}^{-1}, a\left(H^{+}\right)$ is the $\mathrm{H}^{+}$activity, $m$ is the experimentally derived reaction order with respect to the solution $\mathrm{H}^{+}$concentration and $A$ is the specific surface area of each apatite-containing particle in $\mathrm{m}^{2} \mathrm{~g}^{-1}$. The function $f$ (Cama et al., 1999) depends on the solution saturation state $(0 \leq f \leq 1)$ and is given by

$f=1-Q / K_{\mathrm{Eq}}$,

where $Q$ is the reaction activity quotient, $K_{\mathrm{Eq}}$ is each apatite equilibrium constant and $Q / K_{\mathrm{eq}}$ is the fraction that expresses the state of saturation of the solution (with respect to the apatite), calculated every time step in the model. Thus, when $f=1$, the solution is far from equilibrium; therefore, the dissolution rate becomes maximum, while as $f$ approaches 0 , the solution approaches equilibrium with any remaining undissolved FAP and HAP.

HAP is experimentally found to be roughly 3 orders of magnitude more soluble than FAP $\left(K_{\mathrm{Eq}}(\mathrm{HAP})=10^{-20.47}\right.$ vs. 
Table 2. Fluorapatite (FAP) acid dissolution constants used for this study.

\begin{tabular}{lrlrrr}
\hline Mineral $^{\mathrm{e}}$ & $\mathrm{pH}$ & $\begin{array}{l}\mathrm{K}(T) \\
\left(\mathrm{mol} \mathrm{m}^{-2} \mathrm{~s}^{-1}\right)\end{array}$ & $\mathrm{m}$ & $\begin{array}{r}A_{\mathrm{MIN}} \\
\left(\mathrm{m}^{2} \mathrm{~g}^{-1}\right)\end{array}$ & $\mathrm{K}_{\mathrm{eq}}$ \\
\hline FAP & $<5.5$ & $5.75 \times 10^{-6} \exp \left[4.1 \times 10^{3}(1 / 298-1 / T)\right]^{\mathrm{a}}$ & $0.81^{\mathrm{a}}$ & $\begin{array}{r}10.7^{\mathrm{b}} \\
(\text { FAP })\end{array}$ & $\begin{array}{r}10^{-23.12^{\mathrm{d}}} \\
(\mathrm{FAP})\end{array}$ \\
& $5.5-6.5$ & $6.91 \times 10^{-8} \exp \left[4.1 \times 10^{3}(1 / 298-1 / T)\right]^{\mathrm{a}}$ & $0.67^{\mathrm{a}}$ & & \\
& $>6.5$ & $6.53 \times 10^{-11} \exp \left[4.1 \times 10^{3}(1 / 298-1 / T)\right]^{\mathrm{a}}$ & $0.01^{\mathrm{a}}$ & $80.5^{\mathrm{c}}$ & $10^{-20.47^{\mathrm{d}}}$ \\
& & & $(\mathrm{HAP})$ & $(\mathrm{HAP})$ \\
\hline
\end{tabular}

${ }^{a}$ Guidry and Mackenzie (2003). ${ }^{b}$ Bengtsson et al. (2007). ${ }^{c}$ Bengtsson et al. (2009). ${ }^{d}$ van Cappellen and Berner (1991). ${ }^{\text {e }}$ For HAP dissolution constants, we assume those of FAP, as adopted from Guidry and Mackenzie (2003) and corrected based on Palandri and Kharaka (2004) reviewed data (see Sect. 2.2).

$\left.K_{\mathrm{Eq}}(\mathrm{FAP})=10^{-23.12}\right)$, as reported by Nenes et al. (2011) based on van Cappellen and Berner (1991). According to the compilation of experimental determinations of P-dissolution rates of HAP and FAP by Palandri and Kharaka (2004), the dissolution rate of HAP is found to be about an order of magnitude slower than that of FAP under highly acidic conditions $\left(K(\mathrm{HAP})=10^{-4.29}\right.$ and $K(\mathrm{FAP})=10^{-3.73}$ for $\left.\mathrm{pH}=0\right)$, while under neutral conditions, HAP is found to dissolve 2 orders of magnitude faster than FAP $\left(K(\mathrm{HAP})=10^{-6}\right.$ and $\mathrm{K}(\mathrm{FAP})=10^{-8}$ for $\left.\mathrm{pH}=7\right)$. Moreover, HAP is measured to have an almost 8 times larger specific surface area $\left(80.5 \mathrm{~m}^{2} \mathrm{~g}^{-1}\right.$, Bengtsson et al., 2009) compared to that of FAP $\left(10.7 \mathrm{~m}^{2} \mathrm{~g}^{-1}\right)$, which is in agreement with the measured specific surface areas of $8.1-16 \mathrm{~m}^{2} \mathrm{~g}^{-1}$ for sedimentary FAP (Guidry and Mackenzie, 2003). Guidry and Mackenzie (2003) have experimentally derived different rate constants $(K)$ for FAP dissolution ranging from $5.75 \times 10^{-6}$ to $6.53 \times 10^{-11} \mathrm{~mol} \mathrm{~m}^{-2} \mathrm{~s}^{-1}$, with a $\mathrm{pH}$ ranging from 2 to 8.5 . They further derived the respective reaction orders $(m)$ for each $\mathrm{pH}$ region, between 0.01 (for neutral to basic conditions) and 0.81 (for acidic conditions), while the activation energy of the FAP dissolution $\left(E_{\mathrm{a}}\right)$ was calculated as equal to $8.3 \mathrm{kcal} \mathrm{mol}^{-1}$. For the present study, the dissolution reaction coefficient $K$ for FAP (Table 2) is based on the dissolution experiments by Guidry and Mackenzie (2003) for a range of $\mathrm{pH}$ values $(2-12)$, temperatures $\left(25-55^{\circ} \mathrm{C}\right)$ as well as for various solution saturation states and ionic strengths.

Bengtsson et al. (2009) have experimentally studied the solubility and the surface complexation of nonstoichiometric synthetic HAP, identifying three distinct $\mathrm{pH}$ regions for their batch dissolution experiments: (1) under acidic $\mathrm{pH}(<4.5)$, where HAP dissolution is relatively high, producing high concentrations of $\mathrm{Ca}^{2+}$ and $\mathrm{H}_{2} \mathrm{PO}_{4}^{-}$; (2) under basic $\mathrm{pH}(>8.2)$, where surface complexation is the main process; and (3) under intermediate $\mathrm{pH}(4.5-8.2)$, where both dissolution and surface complexation occur. However, they do not provide sufficient information to enable parameterizing HAP dissolution similarly to FAP dissolution. Therefore, for HAP dissolution kinetics, we use the dissolution rates of FAP after correcting them to account for the differences be- tween HAP and FAP dissolution kinetics as a function of $\mathrm{pH}$ and T, as reported by Palandri and Kharaka (2004). For this, we consider the different dissolution rates for a $\mathrm{pH}$ range of 0 to $7-8$, which is the range of acidity encountered by atmospheric particles, including dust (e.g., Bougiatioti et al., 2016; Weber et al., 2016). At the strongly acidic limit $\left(25^{\circ} \mathrm{C}\right.$ and $\mathrm{pH}=0$ ), the dissolution rate of HAP is assumed here to be about $27 \%$ (i.e., $10^{-0.56}$ times) slower than that of FAP, but for neutral and basic conditions (and $25^{\circ} \mathrm{C}$ ) HAP dissolves 2 orders of magnitude faster than FAP (Palandri and Kharaka, 2004). The dissolution rate also changes with temperature; we assume that HAP dissolution has a similar activation energy to FAP (Palandri and Kharaka, 2004; Guidry and Mackenzie, 2003). Additional details for the FAP and HAP mineral dissolution rate parameters are presented in Table 2 .

\subsection{Observation data for model evaluation}

The evaluation of the global atmospheric $\mathrm{P}$ cycle for the present study has been performed based on available observations of aerosol concentrations (Table S1 in the Supplement) and deposition fluxes (Table S2) from various locations around the globe (cruises and land-based stations). The methodological details of the observations used for this study are well documented in the literature and thus are not reviewed here in detail. For DP concentrations in ambient aerosols, we compiled cruise observations of $\mathrm{PO}_{4}$ over the Atlantic Ocean $\left(50^{\circ} \mathrm{N}-50^{\circ} \mathrm{S}\right)$ from Baker et al. (2010), over the western Pacific $\left(25^{\circ} \mathrm{N}-20^{\circ} \mathrm{S}\right)$ from Martino et al. (2014) and over the eastern tropical North Atlantic Ocean $\left(58^{\circ} \mathrm{S}-35^{\circ} \mathrm{N}, 14-38^{\circ} \mathrm{W}\right)$ from Powell et al. (2015). For these oceanic cruise observations, samples were either collected and separated into fine-mode (aerodynamic particle diameter $<1 \mu \mathrm{m})$ and coarse-mode $(1 \mu \mathrm{m}<$ aerodynamic particle diameter) particles using cascade impactors that may include or exclude particles with diameters larger than $10 \mu \mathrm{m}$, or using a single bulk filter. We additionally use average $\mathrm{PO}_{4}$ concentrations (aerodynamic particle diameter $<10 \mu \mathrm{m}$ ) from cruise measurements over Bay of Bengal and the Arabian Sea (Srinivas and Sarin, 2012, 2013, 2015). Finally, we also took 
into account land-based TP and $\mathrm{PO}_{4}$ aerosol concentration measurements from two sites in the Mediterranean: (i) the Finokalia monitoring station $\left(35^{\circ} 20^{\prime} \mathrm{N}, 25^{\circ} 40^{\prime} \mathrm{E}\right)$ located in the eastern Mediterranean (Crete, Greece) and (ii) Ostriconi $\left(42^{\circ} 40^{\prime} \mathrm{N}, 09^{\circ} 04^{\prime} \mathrm{E}\right)$ located in the western Mediterranean (Corsica, France). The samples at both sites were collected either separating the fine (aerodynamic particle diameter $<1.3 \mu \mathrm{m})$ and coarse mode $(10 \mu \mathrm{m}>$ aerodynamic particle diameter $>1.3 \mu \mathrm{m}$; Koulouri et al., 2008; Mihalopoulos and co-workers, unpublished data) or as bulk (Markaki et al., 2010). Details about the characteristics of these Mediterranean sampling sites can be found in Markaki et al. (2010), while the methodology for aerosol sampling and analysis is described in detail in Koulouri et al. (2008).

Although P deposition flux data are rather limited on a global scale, for the present study, we use the wet and dry deposition fluxes (both for TP and DP) compiled by Vet et al. (2014; R. Vet, personal communication, 2016). For wet deposition of DP, we use available filtered (i.e., analyzed as orthophosphates with no digestion as DIP) and unfiltered (i.e., analyzed as orthophosphates following digestion as total DP) annual measurements (Fig. 8.2 in Vet et al., 2014). For the TP wet deposition measurements, we use annual wet deposition measurements (Fig. 8.3 in Vet et al., 2014) of unfiltered samples. The compilation of the phosphorus dry deposition fluxes by Vet et al. (2014) is based on airborne phosphorus (TP and $\mathrm{PO}_{4}$ ) concentrations from around the world and gridded annual dry deposition velocities from the Mahowald et al. (2008) modeling study (Fig. 8.6 and 8.7 in Vet et al., 2014). The size distribution used in these dry deposition calculations is the same as in the modeling study by Mahowald et al. (2008); thus, the derived dry deposition fluxes account for particles with diameter up to $10 \mu \mathrm{m}$. Finally, we also take into account DP wet and dry deposition observations from the Finokalia station in the eastern Mediterranean (Markaki et al., 2010; Mihalopoulos and co-workers, unpublished data), based on rain water samplings (wet-only collector) and glass-bead devices, respectively. Further details on the methodology of the deposition measurements at Finokalia can be found in Markaki et al. (2010).

\section{Results and discussion}

\subsection{Sources of atmospheric phosphorus}

Figure 2 presents the annual mean primary TP and DP emissions from the various sources taken into account in the model (the emission distribution per source for TP and DP are also presented in Figs. S1 and S2 in the Supplement, respectively). TP emissions (Fig. 2a) maximize over the major deserts of the world (e.g., Sahara, Gobi, Arabian, Kalahari, North American and Australian deserts) with simulated $\mathrm{P}$ fluxes up to $100 \mathrm{ng}-\mathrm{P} \mathrm{m}^{-2} \mathrm{~s}^{-1}$ (Figs. 2a and S1a). Secondary maxima of TP emission fluxes of about $0.1-1 \mathrm{ng}-\mathrm{P} \mathrm{m}^{-2} \mathrm{~s}^{-1}$ are also calculated over the midlatitudes of the Northern Hemisphere (NH), such as in China, Europe and the USA, due to release of TP to the atmosphere in ash produced during combustion processes of anthropogenic origin (Fig. S1b) and over forested areas in equatorial America. Additionally, during biomass burning episodes, TP is further released to the atmosphere (Fig. S1c), however, at rates about 1 order of magnitude lower than those of combustion of anthropogenic origin (roughly $0.01 \mathrm{ng}-\mathrm{P} \mathrm{m}^{-2} \mathrm{~s}^{-1}$ ).

The same pattern (as for TP emissions) is simulated for the P-soluble fraction (Fig. 2b), but with lower emission fluxes (e.g., about $1 \mathrm{ng}-\mathrm{P} \mathrm{m}^{-2} \mathrm{~s}^{-1}$ over the Sahara). This is attributed to the solubility of P-containing mineral dust at emission that corresponds to the DP present in the desert soil due to weathering. As discussed in Sect. 2.1.2, this fraction is taken equal to $10 \%$ for the present study. Associated mineral DP emissions (Fig. S2a) of $0.106 \mathrm{Tg}-\mathrm{P} \mathrm{yr}^{-1}$ (as $\mathrm{PO}_{4}$ and/or DOP) occur mainly over the Saharan desert region, but significant fluxes are also calculated to occur over other important deserts of the globe. Anthropogenic DP emissions $\left(0.021 \mathrm{Tg} \mathrm{Pyr}^{-1}\right)$ occur mainly over densely populated regions of the globe (e.g., the midlatitudes of the NH such as China, Europe and the USA), with simulated fluxes up to $0.1 \mathrm{ng}-\mathrm{P} \mathrm{m}^{-2} \mathrm{~s}^{-1}$ (Fig. S2b). DP emissions from biomass burning contribute about $0.009 \mathrm{Tg}-\mathrm{P} \mathrm{yr}^{-1}$, peaking over intense biomass burning areas, e.g., tropical and high-latitude forests and showing maxima over central Africa, Indonesia and Amazonia (Fig. S2c).

The present-day annual apatite dissolution flux is calculated as equal to $0.144 \mathrm{Tg}^{-} \mathrm{P} \mathrm{yr}^{-1}$ (Table 3, Fig. 2c). Most of the apatite dissolution fluxes occur downwind of the major dust source regions (i.e., Nigeria downwind of the Sahara, Pakistan downwind of the Thar Desert and China downwind of the Gobi Desert). Over these regions, the long- and regional-range transport of natural and anthropogenic pollutants enhance atmospheric acidity, and subsequently, $\mathrm{P}$ is mobilized from mineral apatite. The model calculates maximum dissolution fluxes downwind of the Sahara and the Gobi Desert, over the Persian Gulf, the whole Middle East and the Mediterranean basin as well as over the equatorial Atlantic. In addition, enhanced apatite dissolution is calculated over the tropical Atlantic Ocean, India and the outflow of Asia to the Pacific Ocean, in line with observations of changes in solubility during transport of dust across the tropical Atlantic Ocean by Baker et al. (2006a).

As explained in Sect. 2, for the present study the apatite dissolution (Fig. 2c) is due to the respective FAP and HAP solubilizations that occur both in aerosol water and cloud droplets (Fig. S3). The model calculates that most of the apatite dissolution $\left(0.111 \mathrm{Tg}^{-} \mathrm{P} \mathrm{yr}^{-1}\right)$ is occurring in deliquesced particles (Figs. 3, S3a and b), mainly attributed to the higher aerosol acidity, while only $0.034 \mathrm{Tg}^{-\mathrm{P} \mathrm{yr}^{-1}}$ is calculated to occur in cloud droplets (Figs. 3b, S3c and d). Note that the model-calculated global mean $\mathrm{pH}$ in clouds is about 4.5 (Myriokefalitakis et al., 2015). In addition, the distribu- 
Table 3. Secondary DP sources (in Tg-P $\mathrm{yr}^{-1}$ ) due to OP ageing contained in biomass burning, anthropogenic combustion, sea spray and dust as well as due to dust (apatite) dissolution via the acid-solubilization mechanism, as calculated by the TM4-ECPL model for PAST, PRESENT and FUTURE simulations.

\begin{tabular}{llrrrrrr}
\hline & & & & & \multicolumn{2}{c}{ Dust ageing } \\
\cline { 5 - 8 } & TM4-ECPL & $\begin{array}{r}\text { Biomass burning } \\
\text { ageing }\end{array}$ & $\begin{array}{r}\text { Anthropogenic } \\
\text { combustion ageing }\end{array}$ & $\begin{array}{r}\text { PBAPs } \\
\text { ageing }\end{array}$ & $\begin{array}{r}\text { Sea spray } \\
\text { ageing }\end{array}$ & $\begin{array}{r}\text { OP } \\
\text { ageing }\end{array}$ & $\begin{array}{r}\text { Apatite } \\
\text { dissolution }\end{array}$ \\
\hline DP & PAST & 0.002 & 0.001 & 0.016 & 0.0001 & 0.007 & 0.085 \\
& PRESENT & 0.003 & 0.005 & 0.016 & 0.0001 & 0.008 & 0.144 \\
& FUTURE & 0.003 & 0.001 & 0.016 & 0.0001 & 0.008 & 0.100 \\
\hline
\end{tabular}

(a)
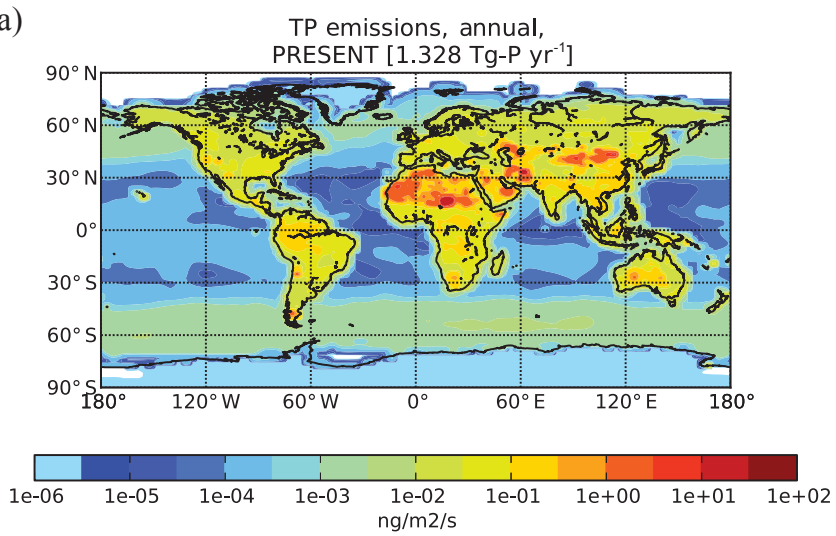

(c)
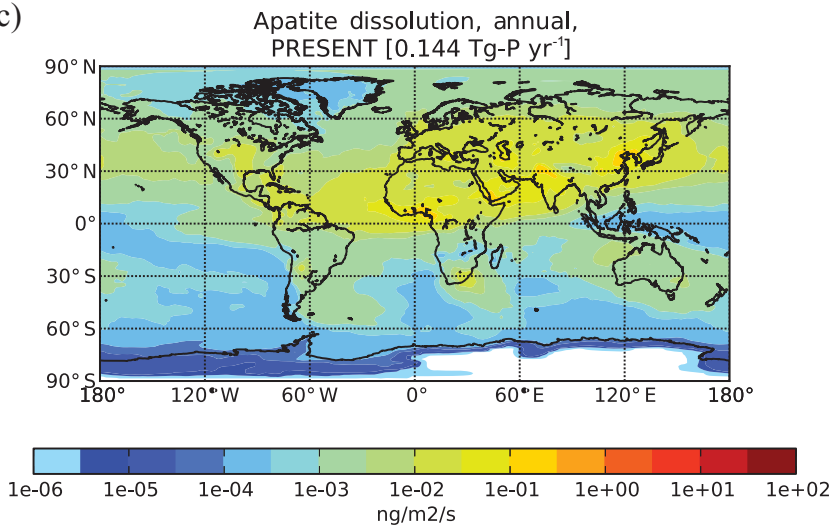

(b)
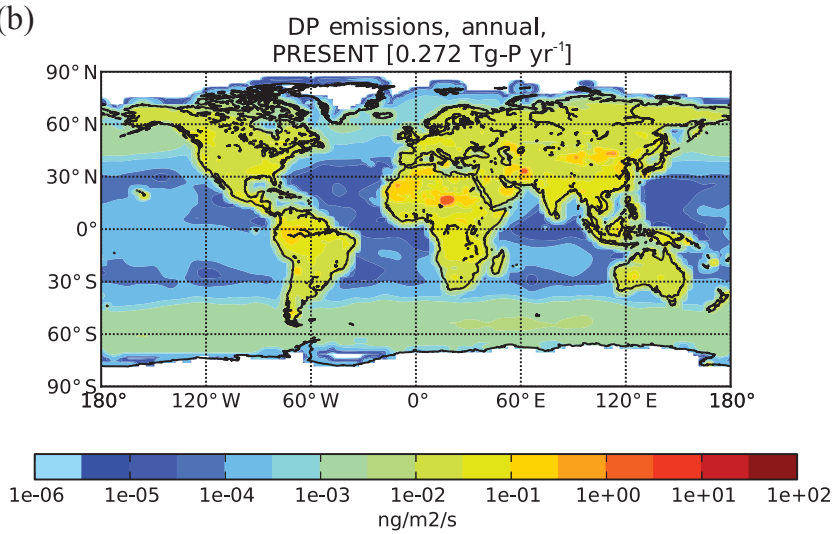

(d)
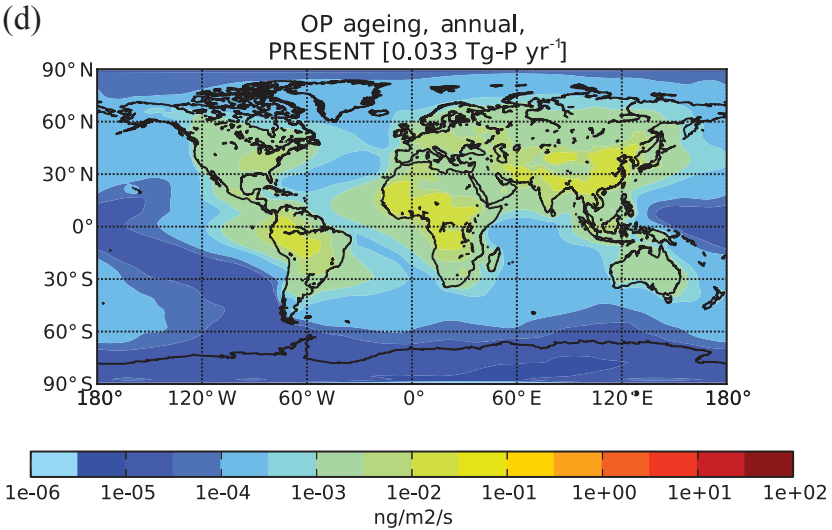

Figure 2. Annual averaged column distributions (in $n g-\mathrm{Pm}^{-2} \mathrm{~s}^{-1}$ ) of the (a) TP emissions, (b) DP emissions, (c) DIP flux from apatite dissolution and (d) DOP production due to OP atmospheric ageing, as calculated by the TM4-ECPL model for the present atmosphere (year 2008).

tions of aerosol and cloud dissolution of apatite are rather different (Fig. 3a,b). In-cloud dissolution is calculated to maximize (i) offshore from the African continent (i.e., over Cote d'Ivoire, Nigeria and Cameroon) over the equatorial Atlantic Ocean and (ii) over China and India, where dust aerosols downwind of major desert regions (i.e., the Sahara and the Gobi Desert, respectively) meet polluted and acidic cloud droplets, while dissolution in aerosol water also shows high rates over the USA, Europe and Saudi Arabia.

DIP fluxes from HAP dissolution in the cloud droplets (Fig. S3d) are calculated to be roughly $60 \%$ higher than those of FAP (Fig. S3c; 0.021 against $0.013 \mathrm{Tg}^{-\mathrm{P} \mathrm{yr}}{ }^{-1}$ ). However, for the DIP dissolution fluxes from the FAP and the HAP in aerosol water, no differences are calculated (Fig. S3a and b) for the more acidic environmental in the fine aerosol water $\left(0.015 \mathrm{Tg}_{-} \mathrm{P} \mathrm{yr}^{-1}\right.$ for each of them). On the contrary, the HAP is more soluble than FAP in the less acidic coarse aerosol water $\left(0.041 \mathrm{Tg}^{-\mathrm{P} \mathrm{yr}^{-1}}\right.$ for the HAP compared to $0.039 \mathrm{Tg}^{-} \mathrm{P} \mathrm{yr}^{-1}$ for the FAP; see also Fig. S2 in the Supplement of Myriokefalitakis et al., 2015 for $\mathrm{pH}$ calculations in the model). The changes in the saturation factor $(f)$ in the aerosol water are also of importance. Under conditions 
(a)
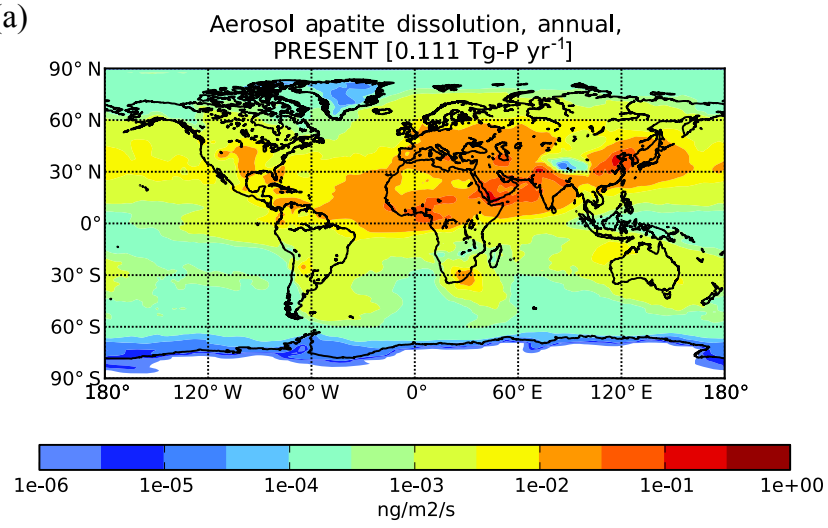

(b)

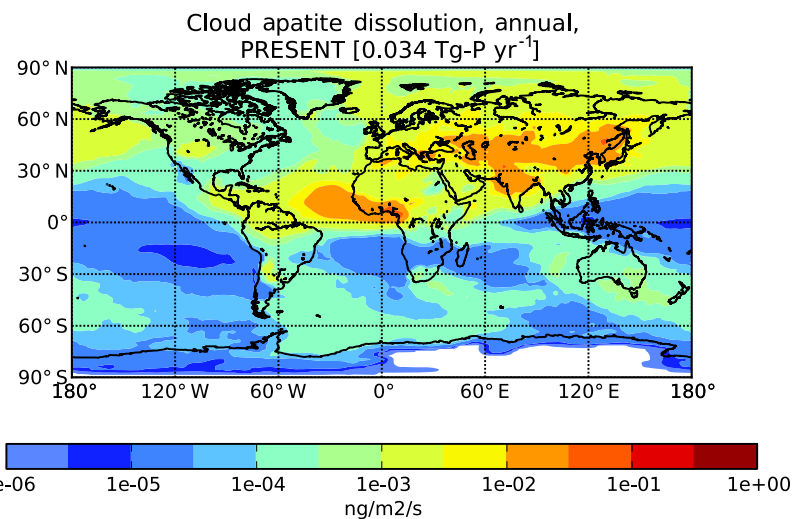

Figure 3. DIP annual fluxes (in ng- $\mathrm{Pm}^{-2} \mathrm{~s}^{-1}$ ) from apatite dissolution (a) in aerosol water and (b) in cloud droplets, as calculated by the TM4-ECPL model for the present atmosphere (year 2008).

where HAP is more soluble than FAP, the respective mobilized $\mathrm{PO}_{4}$ concentrations increase faster in the aerosol solution and react with the soluble $\mathrm{Ca}^{2+}$ present in dust, ultimately forming amorphous apatite that precipitates from the solution (i.e., $f=1$; thus, the dissolution process stops). In the presence of soluble $\mathrm{Ca}^{2+}$ and $\mathrm{PO}_{4}$, other salts, such as monenite $\left(\mathrm{CaHPO}_{4}\right.$; Somasundaran et al., 1985), can also be formed and further impact the solution's degree of saturation. These results suggest that the solution saturation effect in dust aerosol water can be a critical control on the observed $\mathrm{PO}_{4}$ enhancement in acidic atmosphere conditions.

Finally, a significant amount of DOP $\left(0.032 \mathrm{Tg}^{-} \mathrm{P} \mathrm{yr}^{-1}\right)$ is added to the total DP sources due to the ageing of OPcontaining aerosols during atmospheric transport (Table 3). This amount corresponds to about $12 \%$ of the global DP primary emission sources and to roughly $22 \%$ of the total dust-P acid-solubilization flux on a global scale. The ageing of organic-aerosol-carrying $\mathrm{P}$ presents maxima over forested areas (about $0.1 \mathrm{ng}-\mathrm{P} \mathrm{m}^{-2} \mathrm{~s}^{-1}$ ) due to the high oxidation of PBAPs (Fig. 2d). Secondary maxima are also calculated over China (0.01-0.1 ng-P m $\left.{ }^{-2} \mathrm{~s}^{-1}\right)$ and attributed to ageing of primary OP of anthropogenic origin. Downwind of desert source regions, significant DOP production rates, up to $0.1 \mathrm{ng}-\mathrm{P} \mathrm{m}^{-2} \mathrm{~s}^{-1}$, are calculated over the Sahara, the Thar and Gobi deserts; however, these DP formation rates are more localized over continental regions than those due to acid-solubilization mechanism of the dust mineral content (Fig. 2c). However, non-negligible production of DOP is also calculated over the coastal oceans, owing to the OP ageing under the long-range transport in the atmosphere.

\subsection{Evaluation of phosphorus simulations}

Figure 4 presents the evaluation of present-day model simulation at various locations around the globe (Fig. $4 a$, b; see also Sect. 2.4) against (1) P-containing aerosol airborne concentrations (Fig. 4c, e) and (2) dry deposition fluxes (Fig. 4d, f). $\mathrm{PO}_{4}$ and $\mathrm{TP}$ aerosol concentrations are provided in a daily resolution (except for TP concentrations from the Corsica island which are provided as monthly means) and for different sizes; i.e., fine $\left(\mathrm{PM}_{1}\right.$ or $\left.\mathrm{PM}_{1.3}\right)$ and coarse $\left(\mathrm{PM}_{1}\right.$ to $\left.\mathrm{PM}_{10}\right)$ or $\mathrm{PM}_{10}$ aerosols or as bulk concentrations (Table $\mathrm{S} 1$ ). For this model evaluation, a point-by-point comparison has been performed accounting for the respective daily (or monthly) outputs and aerosol size of each P-containing aerosol component of our model to the corresponding observation database. The normalized mean bias (NMB) for the statistical analysis is calculated as

$\mathrm{NMB}=\frac{\sum_{i=1}^{N}\left(M_{i}-O_{i}\right)}{\sum_{i=1}^{N} O_{i}} \times 100 \%$,

where $O_{i}$ and $M_{i}$ stand for observations and model predictions, respectively, with $N$ to represent the number of pairs (observations, model predictions) that are compared. More information about the model performance per database (cruise and stations) and aerosol size can be found in Fig. S4.

The comparison of all available DP aerosol measurements (fine, coarse and bulk) with the respective model results is presented in Fig. 4c. DP aerosol concentrations from cruise observations are in the range of about $3.1 \times 10^{-6}-4.03 \times 10^{-2} \mu \mathrm{g}-\mathrm{P} \mathrm{m}^{-3}$, while from station observations, this range is about $3.23 \times 10^{-4}-1.37 \times 10^{-1} \mu \mathrm{g}$ $\mathrm{P} \mathrm{m}^{-3}$. The model overestimates the DP cruise observations $(\mathrm{NMB}=21 \%)$ and underestimates the DP concentrations measured at stations $(\mathrm{NMB}=-84 \%)$. Focusing, however, on the size-segregated comparison of aerosol DP (Fig. S4), the model underpredicts the observed concentrations at the Finokalia station, both for fine and coarse particles, implying thus a respective underestimation of $\mathrm{P}$ sources over land. On the contrary, for cruise measurements, the model performs much better both for fine and coarse aerosols as well as bulk observations. Note that the station observations correspond to those of Finokalia and Corsica. Furthermore, only few cruise TP observations are available (Graham and Duce, 1982; Baker et al., 2006a, b) that are discussed later in 


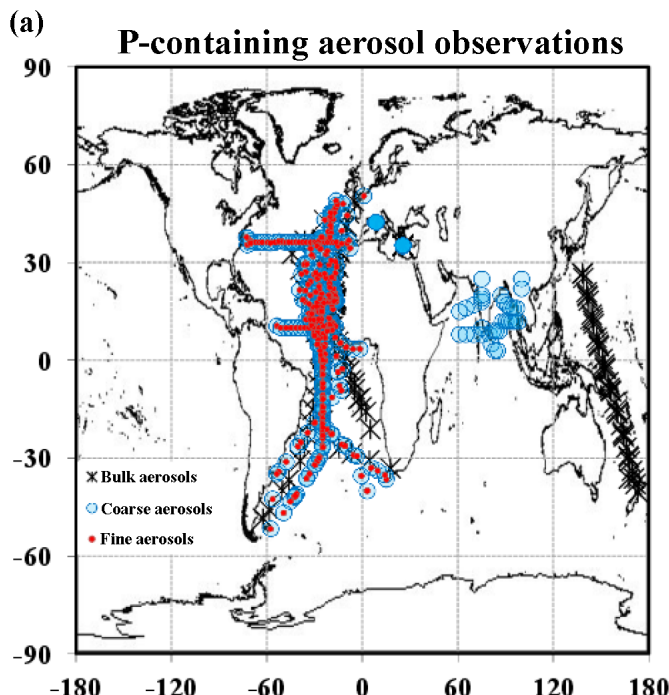

(b)

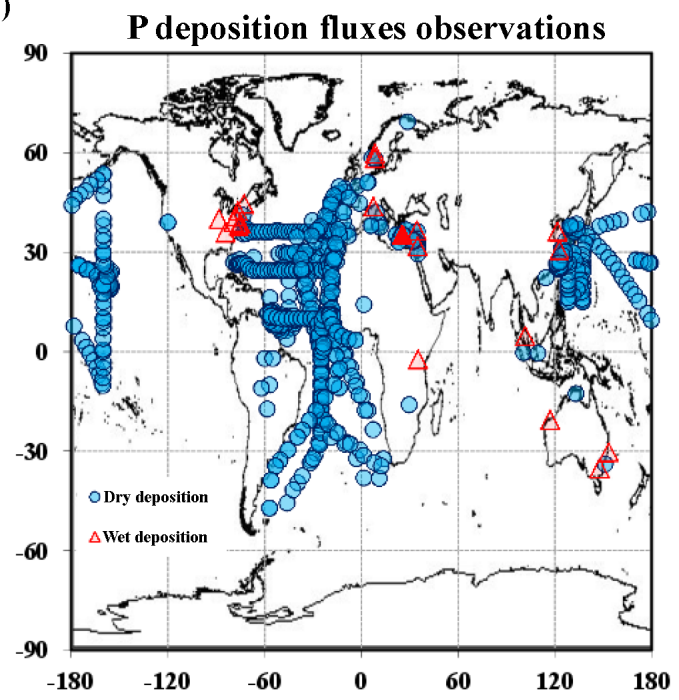

(c)

PO4 aerosol concentrations

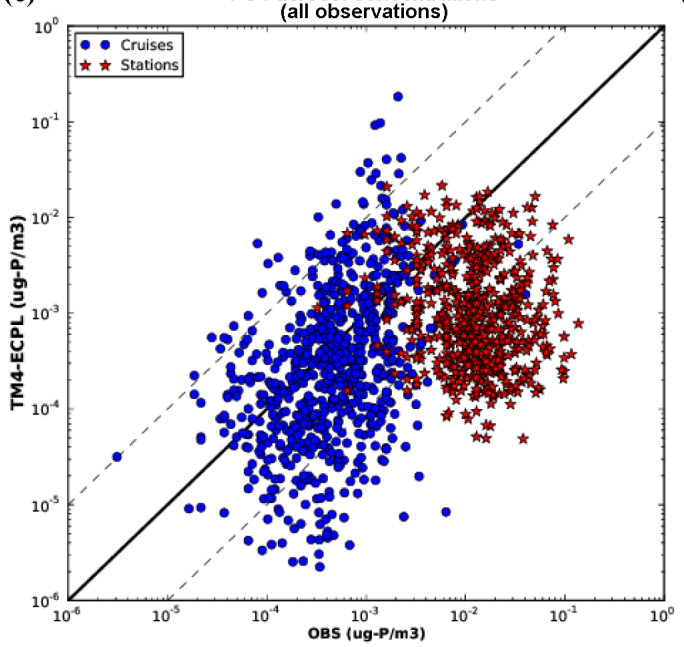

(d)
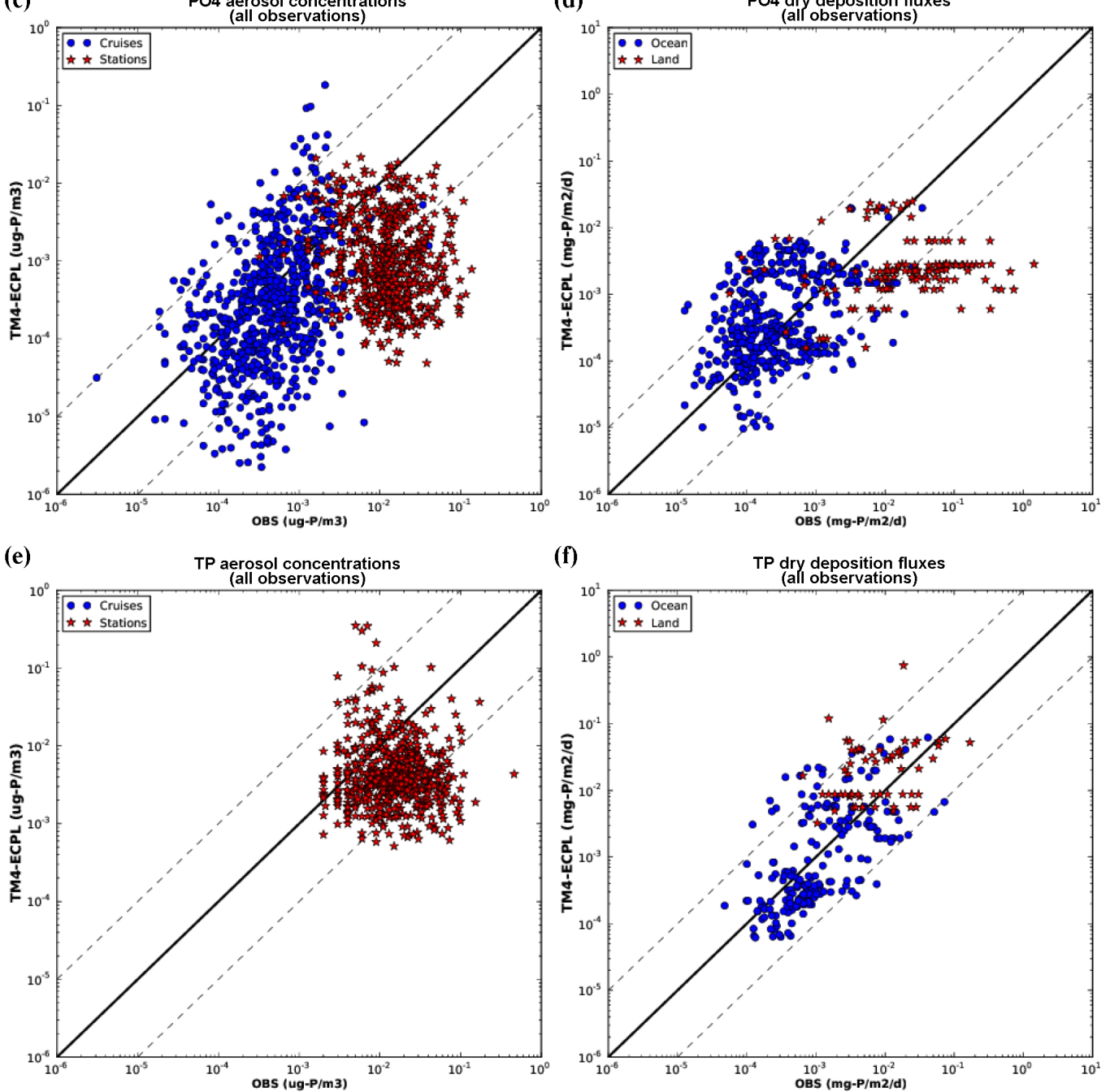

(f)

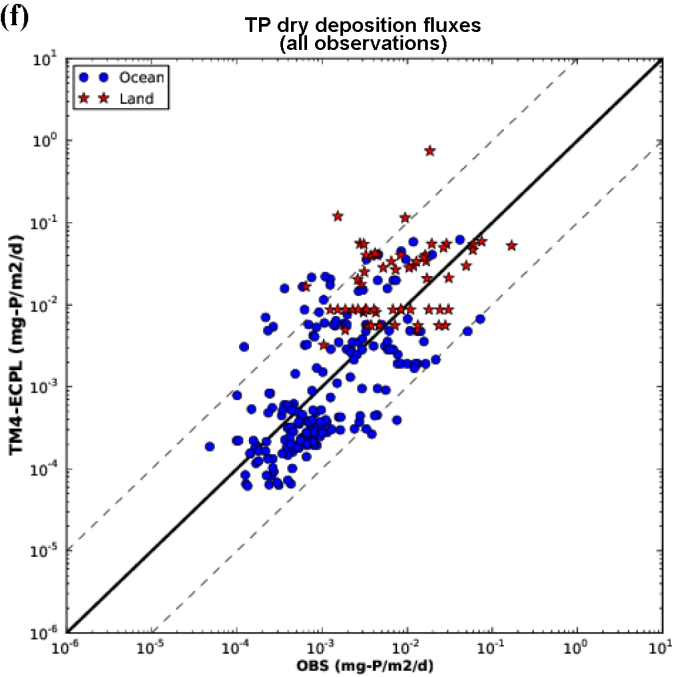

Figure 4. Location of observational data for (a) concentrations of P-containing aerosols (bulk, fine and coarse) and (b) deposition fluxes (wet and dry deposition), (c-f) log scatterplots between model ( $y$ axis) and all observations ( $x$ axis) for surface (c) $\mathrm{PO}_{4}$ and (e) TP aerosol concentrations ( $\mu \mathrm{g}-\mathrm{P} \mathrm{m}^{-3}$ ) measured in cruises (blue dots) and stations (red stars), as well as for (d) $\mathrm{PO}_{4}$ and (f) $\mathrm{TP}$ dry deposition fluxes (mg- $\mathrm{P} \mathrm{m}^{-2} \mathrm{~s}^{-1}$ ) over oceans (blue dots) and inland sites (red stars). The continuous black line shows the $1: 1$ correlation and the dashed black lines show the $10: 1$ and $1: 10$ relationships, respectively. 
(a)
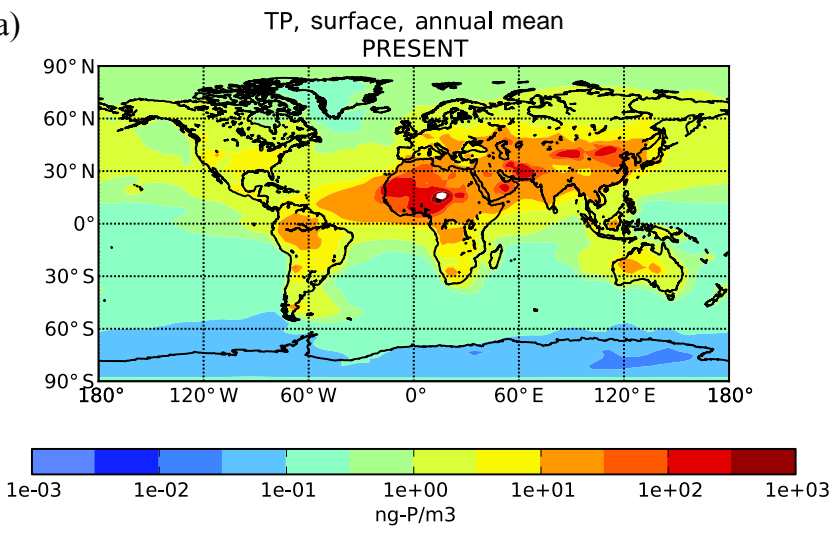

(c)

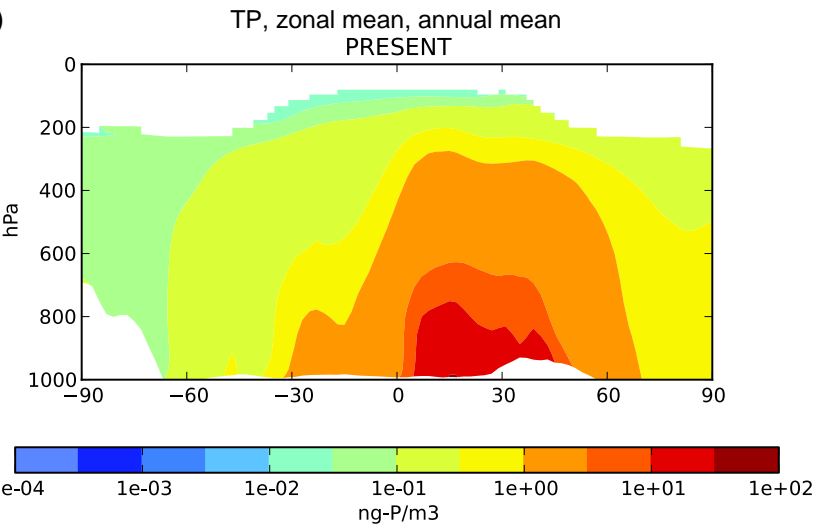

(b)
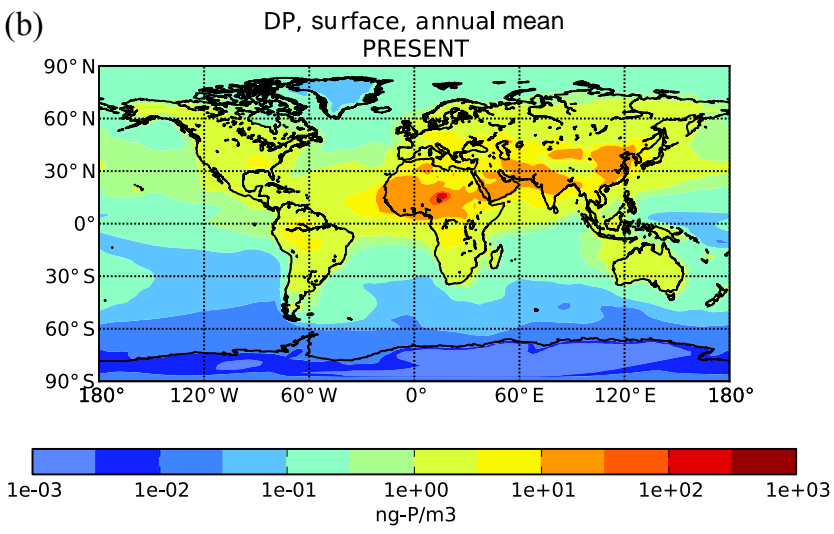

(d)
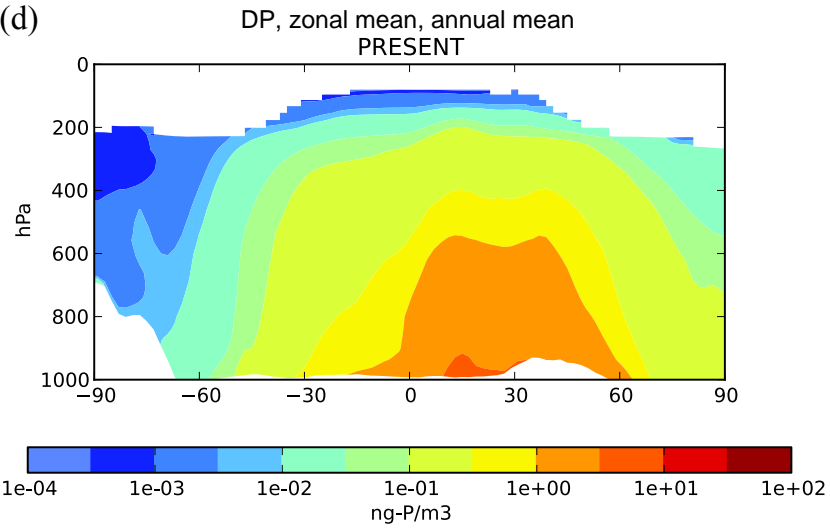

Figure 5. Annual mean concentrations (in ng-P $\mathrm{m}^{-3}$ ) of TP $(\mathbf{a}, \mathbf{c})$ and DP $(\mathbf{b}, \mathbf{d})$ for the surface $(\mathbf{a}, \mathbf{b})$ and in the troposphere as zonal mean (c, d), as calculated by the TM4-ECPL model for the present atmosphere (year 2008).

Sect. 3.5. The comparison presented here also indicates that the model underpredicts $(\mathrm{NMB}=-59 \%)$ the observed $\mathrm{TP}$ concentrations at Finokalia (eastern Mediterranean; see also Fig. S4); however, it simulates the bulk TP aerosol concentrations better at Corsica (western Mediterranean). This implies that our model lacks TP sources in the eastern Mediterranean atmosphere, which is strongly affected by air masses from surrounding regions and by sources other than local ones.

As in the case of DP aerosol concentrations, the model simulates the DP dry deposition fluxes better $(\mathrm{NMB}=52 \%)$ over oceanic regions (airborne cruise measurements compiled by Vet et al., 2014) than the observations (NMB $=-93 \%)$ at the Finokalia station (Fig. 4d). Note that the same pattern is also calculated for the TP dry deposition fluxes (Fig. 4f). The omission of super-coarse marine DP sources associated with sea-salt particles can explain some discrepancies between model results and observations only when these later concern bulk aerosols in oceanic regions (so they could include super-coarse particles), which is the case for wet or dry deposition samples. As discussed in Sect. 2.1.4, this omission can affect local comparisons but overall does not introduce more than a $3 \%$ underestimate of DP flux over the ocean. In many cases, aerosol samples have been collected with inlet devices that enable collection of specific fractions of aerosols and eliminate super-coarse particles. When bulk aerosols have been collected, then the presence of super-coarse aerosols might introduce discrepancies between model results and observations. Overall, the model performs better for DP dry deposition fluxes over the oceans than over land, indicating a possible underestimate in the continental source of $\mathrm{P}$.

In Figs. S4 and S5, the results of sensitivity simulations and the base case simulation are also presented with the aerosol observations and dry and wet deposition fluxes, respectively. Fig. S6 also shows the comparison of the annual cycles of the atmospheric concentrations ( $\mathrm{TP}$ and $\left.\mathrm{PO}_{4}\right)$ and deposition fluxes (dry and wet deposition), against the TM4ECPL monthly model results. For cruise measurements over the Atlantic and Pacific oceans (Baker et al., 2010; Martino et al., 2014; Powell et al., 2015) and the global compilation of deposition rates (Vet et al., 2014), the observations are also spatially averaged inside the same model grid box. These comparisons show almost similar performance for all sensitivity simulations but with one falling, in most cases, close to the lower edge of observed concentrations and deposition fluxes. However, taking into account the Wang et al. (2014) P-combustion sources, the model performs better over the land (e.g., for TP concentrations at Corsica, Fig. S4g; and 
Table 4. Global and oceanic deposition fluxes of TP, DP and BP (in $\mathrm{Tg}-\mathrm{P} \mathrm{yr}^{-1}$ ), as calculated by the TM4-ECPL model for PAST, PRESENT and FUTURE simulations.

\begin{tabular}{llrr}
\hline Deposition & TM4-ECPL & Global & Ocean \\
\hline $\mathrm{TP}$ & PAST & 1.262 & 0.270 \\
& PRESENT & 1.300 & 0.281 \\
& FUTURE & 1.270 & 0.272 \\
\hline $\mathrm{DP}$ & PAST & 0.369 & 0.133 \\
& PRESENT & 0.455 & 0.169 \\
& FUTURE & 0.390 & 0.142 \\
\hline $\mathrm{BP}$ & PAST & 0.384 & 0.135 \\
& PRESENT & 0.470 & 0.172 \\
& FUTURE & 0.405 & 0.144 \\
\hline
\end{tabular}

for DP concentrations at the Finokalia monitoring station, Fig. $6 \mathrm{~b}, \mathrm{f}, \mathrm{i})$, indicating that the base simulation underestimates either anthropogenic combustion sources or other natural P sources. Neglecting the P dissolution definitely degrades the comparisons of model results with observations. On the other hand, the results show very small sensitivity to the assumption of the soluble fraction of the primary emissions of $\mathrm{P}$. This finding supports the importance of the atmospheric processing of dust for the atmospheric DP cycle as well as the potential underestimate of the DP source in all sensitivity simulations. Such an underestimate could be associated with an underestimate in the primary source or in the secondary (atmospheric processing) of DP and deserves further studies.

Considering the scarcity of observational data and the gaps in knowledge of $\mathrm{P}$ emissions and fate in the atmosphere, the simulated atmospheric $\mathrm{P}$ aerosol concentrations $(\mathrm{N}=1885)$ satisfactorily compare with the respective available observations $(\mathrm{NMB}=-67 \%)$ for $\mathrm{TP}(\mathrm{N}=585)$ and $\mathrm{PO}_{4}(\mathrm{~N}=1300)$, and for $\mathrm{P}$ dry deposition fluxes $(\mathrm{N}=819$; $\mathrm{NMB}=-63 \%$ ), indicating, however, an overall model underestimate of the observed values (Fig. 4b). Based on these comparisons, we evaluate that an uncertainty of about $70 \%$ is associated with PRESENT model estimates.

\subsection{Global distribution of atmospheric phosphorus}

TM4-ECPL calculates global TP and DP atmospheric burdens of 0.011 and of $0.003 \mathrm{Tg}-\mathrm{P}$, respectively. The calculated global annual mean TP and DP atmospheric surface distributions for the present day are also shown in Fig. 5a and b. TP surface concentrations maximize over the major dust regions of the world, roughly $0.1-1 \mu \mathrm{g}-\mathrm{P} \mathrm{m}^{-3}$ (Fig. 5a), where P-containing dust particles dominate the TP burden. Secondary maxima are calculated over central Africa, Asia and Indonesia, where significant TP concentrations (10-100 ng$\mathrm{P} \mathrm{m}^{-3}$ ) are associated with biomass burning emissions and PBAPs (Fig. 5a). Over the oceans, however, TP concentra- tions maximize downwind of dust source regions (roughly $10-100 \mathrm{ng}^{-\mathrm{P} \mathrm{m}^{-3}}$ ) and secondary maxima of about $1-10 \mathrm{ng}$ $\mathrm{P} \mathrm{m}^{-3}$ are calculated due to long-range transport from continental sources, mainly over the $\mathrm{NH}$.

Annual mean DP concentrations of $100 \mathrm{ng}-\mathrm{P} \mathrm{m}^{-3}$ are calculated to occur over the Sahara, the Arabian and Gobi deserts near the surface (Fig. 5b). The outflow from these source regions transports DP over the global ocean where annual mean concentrations of about $10 \mathrm{ng}-\mathrm{P} \mathrm{m}^{-3}$ are calculated downwind of dust source regions, with the highest impact calculated for the tropical Atlantic Ocean. The simulated concentrations of DP over polluted regions range from 1 to $10 \mathrm{ng}-\mathrm{P} \mathrm{m}^{-3}$, further highlighting the importance of anthropogenic contributions to the DP atmospheric burden - directly due to combustion emissions and indirectly due to the solubilization of $\mathrm{P}$ when dust is mixed with atmospheric pollution during atmospheric transport (Fig. 5b). TP emissions associated with African dust are calculated to significantly affect the lower troposphere (Fig. 5c). Furthermore, DP shows non-negligible concentrations in the middle troposphere (Fig. 5d) that are attributed to transport from the source regions and to atmospheric ageing (mainly Psolubilization processes) that converts insoluble to soluble $\mathrm{P}$, as already discussed.

\subsection{Present-day phosphorus deposition flux}

TM4-ECPL calculates that $1.300 \mathrm{Tg}^{-} \mathrm{P} \mathrm{yr}^{-1}$ of TP are deposited to the Earth's surface of which about $0.281 \mathrm{Tg}-\mathrm{P} \mathrm{yr}^{-1}$ over the ocean (Table 4). This oceanic deposition flux is calculated to be about half of that estimated by Mahowald et al. $\left(2008 ; 0.558 \mathrm{Tg}^{-} \mathrm{P} \mathrm{yr}^{-1}\right)$ over oceans and at the low end of the deposition flux range calculated by Wang et al. (2014; $0.2-1.6 \mathrm{Tg}^{-} \mathrm{P} \mathrm{yr}^{-1}$ over the ocean). The highest TP annual deposition fluxes (up to $100 \mathrm{ng}-\mathrm{P} \mathrm{m}^{-2} \mathrm{~s}^{-1}$ ) are calculated to occur over the Sahara and the Gobi Desert while deposition fluxes up to $1 \mathrm{ng}-\mathrm{P} \mathrm{m}^{-2} \mathrm{~s}^{-1}$ are also calculated at the outflow from dust source regions, especially over the equatorial Atlantic and northern Pacific oceans (Fig. 6a). The computed global DP deposition is calculated as equal to $0.455 \mathrm{Tg}-\mathrm{P} \mathrm{yr}{ }^{-1}$, of which $0.169 \mathrm{Tg}-\mathrm{P} \mathrm{yr}^{-1}$ is deposited over the ocean (Table 4), which is about $75 \%$ higher than the estimate by Mahowald et al. (2008; $\left.0.096 \mathrm{Tg}_{\mathrm{P} \mathrm{yr}}{ }^{-1}\right)$. The differences between the aforementioned studies can be explained, on one hand, by the P-solubilization processes that only the present study takes into account (and thus a greater amount of $\mathrm{PO}_{4}$ is deposited at the Earth's surface) and, on the other hand, by the different aerosol size representation that impacts on the lifetime of airborne P-containing particles in the atmosphere. For this work, the highest DP deposition fluxes are simulated to occur downwind of dust source regions, owing to the DP content of the primary $\mathrm{P}$ emissions discussed in Sect. 3.1 and to $\mathrm{P}$ solubilization during atmospheric transport (Fig. 6b). Secondary DP deposition flux maxima (about $0.1 \mathrm{ng}-\mathrm{P} \mathrm{m}^{-2} \mathrm{~s}^{-1}$ ) are simulated downwind 
(a)
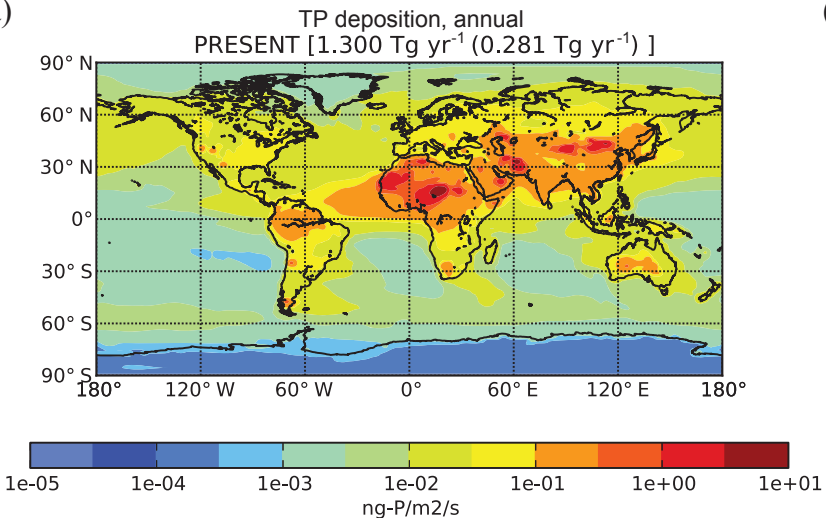

(c)
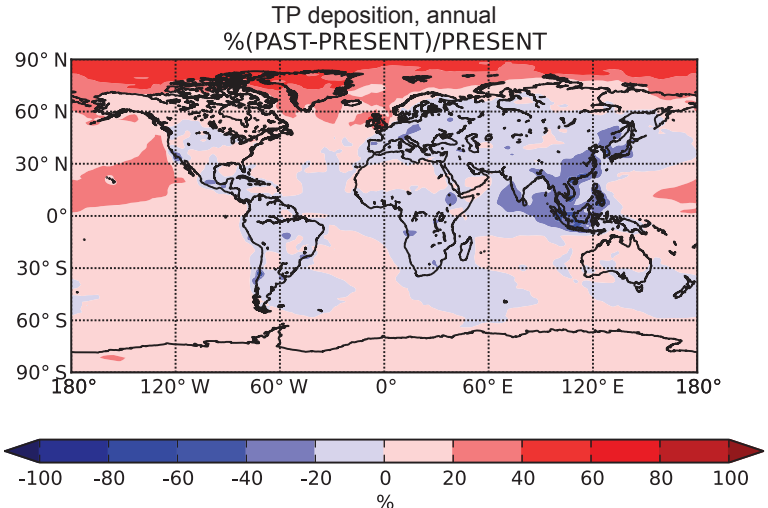

(e)

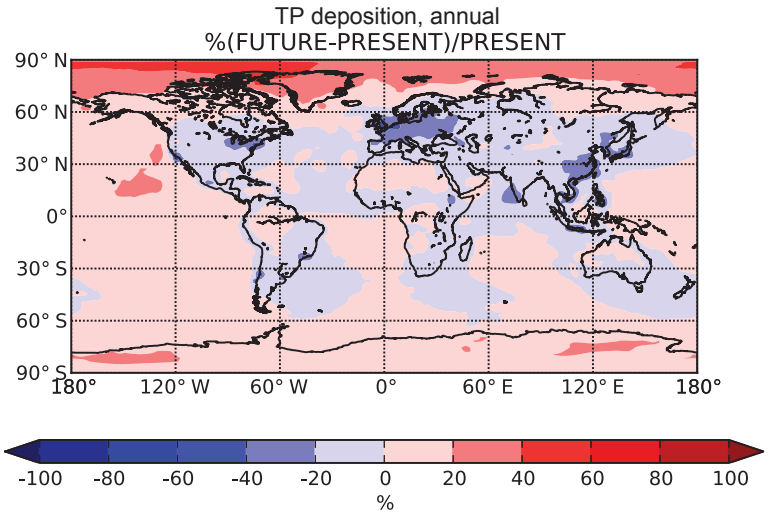

(b)
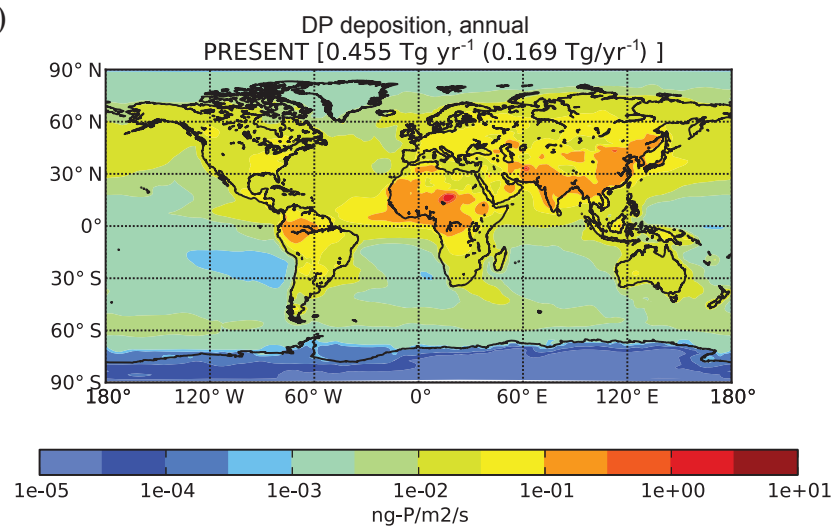

(d)

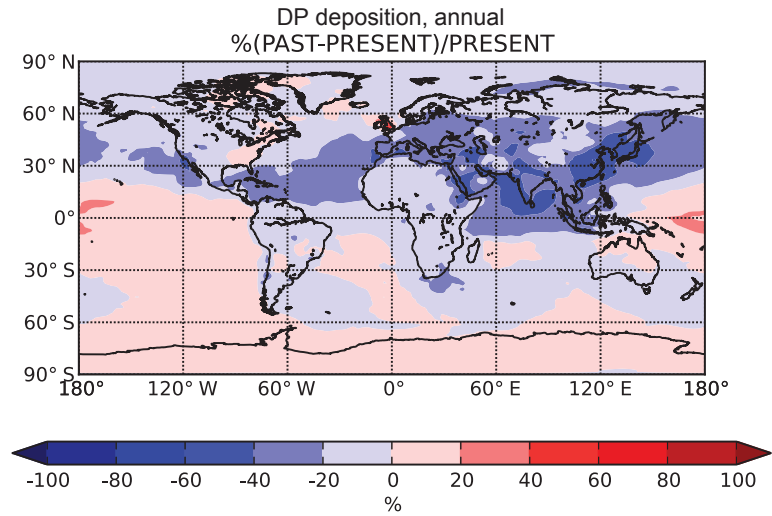

(f)

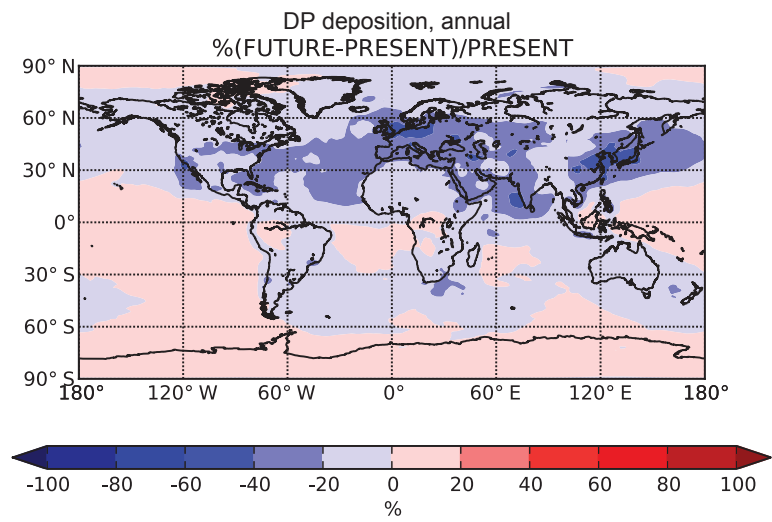

Figure 6. Calculated annual deposition fluxes (in $n g-\mathrm{P} \mathrm{m}^{-2} \mathrm{~s}^{-1}$ ) for (a) TP and (b) DP for PRESENT simulation and their percentage differences from PAST $(\mathbf{c}, \mathbf{d})$ and FUTURE $(\mathbf{e}, \mathbf{f})$ simulations, respectively. For the PRESENT annual deposition fluxes (a, b), within brackets, the total amounts over the globe (in parentheses only over the ocean) are also provided.

of highly forested regions (i.e., Amazonia, central Africa and Indonesia), reflecting the contribution of PBAPs to the DOP concentrations in the atmosphere.

Figure S7 further presents the seasonal variability of DP deposition fluxes as calculated by TM4-ECPL. The maximum seasonal DP deposition flux over the ocean of $0.049 \mathrm{Tg}$ $\mathrm{P}$ is calculated to occur during June-July-August (Fig. S7c), followed by $0.048 \mathrm{Tg}-\mathrm{P}$ during March-April-May (Fig. S7b) and by $0.038 \mathrm{Tg}-\mathrm{P}$ during September-October-November (Fig. S7d). The maximum DP deposition flux in summer oc- curs when ocean stratification also maximizes, thus leading to the highest impact of atmospheric deposition to the marine ecosystems (Christodoulaki et al., 2013). Furthermore, PBAP contribution maximizes in summer at regions with important biogenic emissions (Fig. S8e-h), while dust contribution maximizes in spring mainly over and downwind of the major deserts in the tropical and midlatitudes of the Northern Hemisphere (Fig. S8a-d). This is because the enhanced photochemistry during $\mathrm{NH}$ spring and summer increases atmospheric oxidants and the atmospheric acidity due to $\mathrm{NO}_{x}$ 
(a)
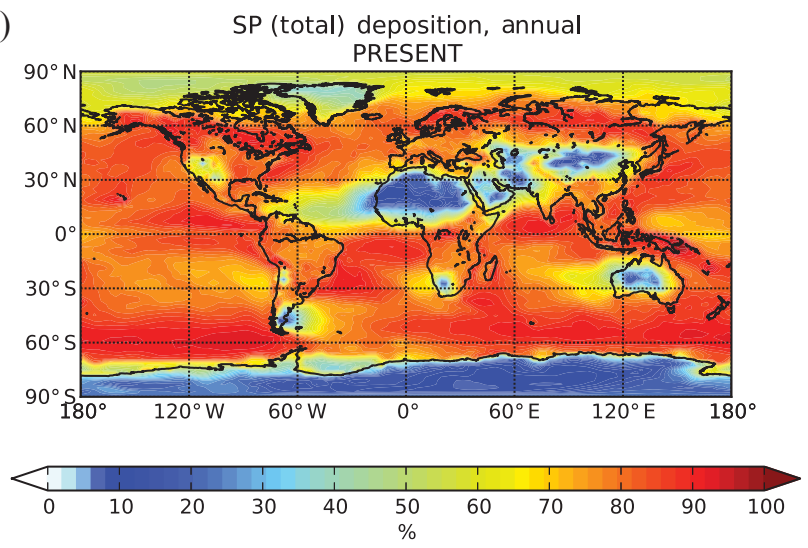

(b)

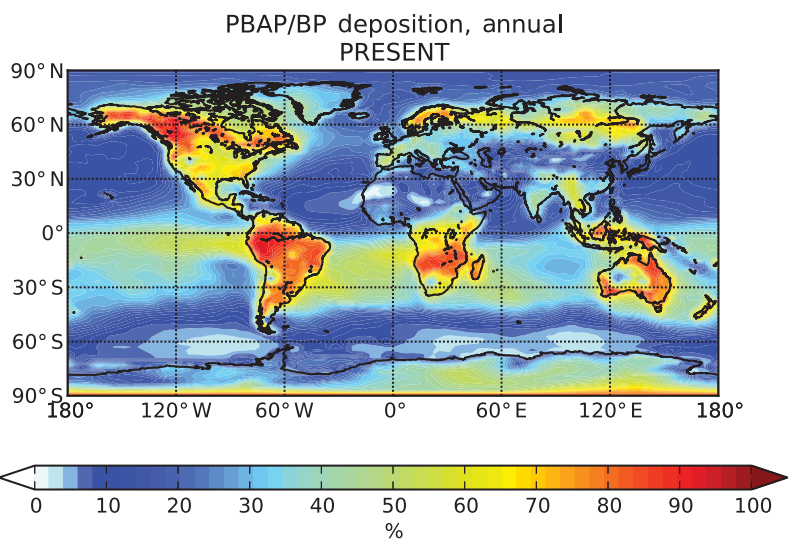

Figure 7. Annual mean percentage fractions of (a) $\mathrm{P}$ solubility $(\mathrm{SP}=\% \mathrm{DP} / \mathrm{TP})$ and $(\mathbf{b})$ the relative contribution of PBAPs to $\mathrm{BP}$, in deposited P-containing aerosols, as calculated by the TM4-ECPL model for the present atmosphere (year 2008).

and $\mathrm{SO}_{x}$ oxidation. Note also that under equinox conditions, in particular in spring, Sahara dust outbreaks are also favored (Fig. S8b). Considering that most TP emissions occur in the NH (Fig. 2a), DP secondary formation from IP and OP sources are simulated to maximize there (Fig. 2c,d), with emissions from biomass burning and combustion of anthropogenic origin further contributing to the DP deposition flux.

\subsection{Phosphorus solubility}

The present-day $\mathrm{P}$ solubility of deposited aerosols (hereafter $\mathrm{SP}=\% \mathrm{DP} / \mathrm{TP}$ ) is calculated to vary spatially (Fig. 7a), with minima (as low as $10 \%$ ) over dust source regions like the Sahara (where the insoluble fraction of TP dominates aerosol content) and maxima (up to roughly $90 \%$ ) over remote oceans such as the equatorial Pacific, southern Atlantic, Indian and Southern oceans. Over such remote oceanic regions, high solubility fractions are calculated due to low Pcontaining aerosol mass concentrations that occur via the long-range transport of fine particles from distant source regions, as well as the $\mathrm{P}$ which is associated with more aged aerosols, and thus a greater fraction is present in the soluble mode, either as DIP via mineral acid-solubilization processes or DOP via atmospheric oxidation of P-containing organic aerosols and as PBAPs. Vet et al. (2014), in their review paper of nutrient deposition, also mentioned that the $\mathrm{P}$ solubility fractions of wet-only samples on coastal and inland sites have been measured to range from 30 to $90 \%$, thus reflecting the effects of combustion, biomass burning and phosphate fertilizers on airborne phosphorus concentrations. Anderson et al. (2010) reported that only $15-30 \%$ of $P$ in atmospheric aerosols at the Gulf of Aqaba was in water-soluble phases or relatively soluble to be bioavailable to the ecosystems. In the Mediterranean, the measured median solubilities of the inorganic fraction of $\mathrm{P}$ in aerosols (ratio of $\mathrm{PO}_{4}$ to total inorganic $\mathrm{P}$ ) range between 20 and $45 \%$ in the east Mediterranean with the lowest values in dust-influenced air masses and the highest values in air masses from the European continent (Markaki et al., 2003; Herut et al., 1999) and have been reported to be around $38 \%$ in the west Mediterranean (Markaki et al., 2010). However, simultaneous observations of TP and DP deposition fluxes are required to evaluate the solubility fraction of $\mathrm{P}$ (both organic and inorganic) over remote oceans and thus to understand the atmospheric fate of $\mathrm{P}$. There are only a few aerosol data available in the literature for the marine atmosphere (Graham and Duce, 1982; Baker et al., 2006a, b; Zamora et al., 2013) that provide hints on the total $\mathrm{P}$ solubility. These data indicate $\mathrm{P}$ solubilities ranging overall between 0.01 and $94 \%$, with the lowest values corresponding to dust-influenced air masses and the highest to sea-salt-influenced air masses. Over the Northern Hemisphere, Atlantic Ocean P solubilities in aged Saharan dust aerosols have been measured to range from 0.01 to $37 \%$ during oceanographic cruises (Baker et al., 2006a, b). At Barbados, median solubilities of $\mathrm{P}$ on dust of about $19 \%$ and of sea-salt aerosol of about $94 \%$ have been reported (Zamora et al., 2013). In the southern Atlantic, atmosphere P solubilities in aerosols of up to $67 \%$ (median $8 \%$ for dust aerosol and $17 \%$ for southern Atlantic aerosol; Baker et al., 2006a) and of up to $87 \%$ (median $32 \%$; Baker et al., 2006b) have been reported. All these studies (but one) report P solubility as the ratio of $\mathrm{PO}_{4}$ to TP, thus neglecting the organic fraction which has been measured to be about $28-44 \%$ (Zamora et al., 2013). Although these observations support high P solubilities in aged aerosols or aerosols impacted by non-dust sources supporting the findings of our modeling study, only the work by Zamora et al. (2013) could be compared to the total P solubility simulated here (Fig. 7a). They indicate that the model-simulated total P solubility is at the upper edge of observed P solubilities.

The soluble $\mathrm{P}$ originating from each source as a fraction of TP from all sources is shown in Fig. S9 for all P source categories (within each model grid, these fractions sum up to $100 \%$ ). Note that in our SP fraction calculations we also include the contribution of DOP from super-coarse PBAPs. This assumption is followed since the DOP from PBAPs is considered readily bioavailable, compared to other super- 
coarse particles, such as dust, for which the bioavailability is characterized mainly from the initial dust's solubility rather than from atmospheric processing due to the short atmospheric lifetime of super-coarse particles. Indeed, supercoarse particles of that size are basically emitted and deposited in the same model grid box (Brahney et al., 2015), and are not therefore expected to significantly impact SP fractions over remote oceanic areas.

The low SP values over dust source regions are mainly attributed to both the relatively low weathering of dust aerosols (10\%) assumed in emission fluxes and low mineral P-dissolution rate (Fig. S9a). The low water associated with dust aerosols near dust sources and the enhanced buffering capacity of dust carbonate leading to excess of $\mathrm{Ca}^{2+}$ concentrations (see Sect. 3.1 and Fig. 2c) thus cause low P dissolution. The model calculates high SP values (up to 50$60 \%$ ) over regions such as the Mediterranean basin, where the co-existence of relatively high dust concentrations and high amounts of anthropogenic pollutants (e.g., Kanakidou et al., 2011) tends to enhance significantly atmospheric processing of mineral P (Nenes et al., 2011). High dust SP values are also calculated over the open ocean of the $\mathrm{NH}$, the Atlantic Ocean, the Pacific Ocean in the outflow of the Americas, downwind of the Arabian Desert over the Indian Ocean and over the European continent. These results are attributed to the mineral $\mathrm{P}$ solubilization under polluted acidic atmospheric conditions.

Anthropogenic combustion aerosols are calculated to contribute significantly to SP (20-30\%) over highly populated regions of the world, mainly over the $\mathrm{NH}$ as in the case of the eastern and the western coasts of the USA, central and northern Europe and western Asia (Fig. S9b). About 5-15\% of the calculated SP over the remote oceans is attributed to long-range transport, where aerosols have been subjected to atmospheric ageing. Biomass burning aerosols are calculated to contribute regionally less than $30 \%$ to SP, with their maximum contribution over the equatorial Atlantic and Indian oceans due to aerosol transport and the atmospheric ageing from central Africa and India (Fig. S9c). DP emissions and atmospheric ageing associated with PBAPs from terrestrial sources including super-coarse P-containing bioaerosols (i.e., pollen in the present study) are calculated to significantly contribute to DP deposition in the tropics (about $50 \%$ in the outflow of Amazonia and central African and Indonesian forests on an annual mean basis; Fig. S9d). Seasonally, this contribution is even higher during summer; for instance, it reaches $60 \%$ in the Mediterranean and $70 \%$ in the outflow over the equatorial Pacific Ocean (not shown). DP from sea spray dominates over all the remote Southern Ocean where no other significant primary source of DP is present (Fig. S9e), while volcanic eruptions contribute to the SP mainly over the equatorial and northern Pacific Ocean (Fig. S9f).

\section{Sensitivity of soluble phosphorus budget to air pollutants}

Atmospheric acidity strongly depends on anthropogenic $\mathrm{SO}_{x}, \mathrm{NO}_{x}$ and $\mathrm{NH}_{x}$ emissions and impacts on dust solubility. It is thus expected to change in response to variability in the anthropogenic emissions of air pollutants (Weber et al., 2016). The response of atmospheric ageing of TP, which potentially converts the insoluble TP fraction to DP, to air pollutant emission changes is assessed here by comparing simulations performed using anthropogenic and biomass burning past and future emissions to the present-day simulation (see Sect. 2). In addition to dust dissolution changes, atmospheric organic aerosol (OA) ageing is also affected by changes in oxidants levels (Tsigaridis and Kanakidou, 2003; Tsigaridis et al., 2006). Furthermore, primary anthropogenic and biomass burning emissions of $\mathrm{P}$ also vary, as shown in Table 1 and discussed in Sect. 2.1. In particular, PRESENT TP anthropogenic emissions are estimated to have increased by a factor of 5 since PAST and to be reduced back to almost the PAST levels in the FUTURE. In the simulations discussed here, meteorology and natural emissions of dust, sea salt, PBAPs and those from volcanoes are kept constant to those of the year 2008 (i.e., PRESENT simulation). Although for this work, we do not account for any changes in atmospheric dust emissions for PAST and FUTURE simulations, several studies suggest that dust may vary strongly and perhaps be sensitive to anthropogenic climate change and land use (Ginoux et al., 2012; Mahowald et al., 2010; Prospero and Lamb, 2003) and thus could also be an important driver of changes in the atmospheric P cycle. Overall, for this study, the computed changes for species that regulate the mineral-P acid solubilization (e.g., $\mathrm{SO}_{4}^{2-}, \mathrm{NO}_{3}^{-}, \mathrm{NH}_{4}^{+}$) are due to the respective combustion emission differences between PAST, PRESENT and FUTURE simulations.

For the PAST simulation, the anthropogenic emissions (e.g., $\mathrm{NO}_{x}, \mathrm{NH}_{x}$ and $\mathrm{SO}_{x}$ ) are a factor of 5-10 lower than present-day emissions (Lamarque et al., 2013). Compared to the present day, the model calculates significant changes in the aerosol $\mathrm{pH}$ in the PAST simulation with less acidic $\mathrm{pH}$ near the surface of the $\mathrm{NH}$ oceans, but a more acidic $\mathrm{pH}$ over the USA due to extensive coal combustion in 1850 (Myriokefalitakis et al., 2015). The FUTURE simulation globally projects a less acidic aerosol $\mathrm{pH}$ than present day (Myriokefalitakis et al., 2015), owing to lower $\mathrm{NO}_{x}$ and $\mathrm{SO}_{x}$ emissions. Indeed, for the FUTURE simulation, anthropogenic emissions (RCP 6.0) for most of the continental areas are projected to be lower than the present day and to almost return to 1850 levels due to air-quality regulations (Lamarque et al., 2013). However, as discussed in Myriokefalitakis et al. (2015) for the atmospheric cycle of Fe, due to the fact that biomass burning emissions are projected to increase in the future, the system does not fully return to 1850 conditions. Past and future changes of the atmospheric acidity have a significant effect on mineral-P dissolution (Fig. S10c, 
d) and on the ageing of atmospheric OP (Fig. S10e, f). For the PAST simulation, the model calculates about $40 \%$ lower acid mineral-P dissolution $\left(0.085 \mathrm{Tg}-\mathrm{P} \mathrm{yr}^{-1}\right)$ compared to present day $\left(0.144 \mathrm{Tg}-\mathrm{P} \mathrm{yr}^{-1}\right)$ while for the FUTURE, the acid mineral-P solubilization $\left(0.100 \mathrm{Tg}-\mathrm{P} \mathrm{yr}^{-1}\right)$ is projected almost $30 \%$ lower than nowadays (Table 3 ).

\subsection{Past and future changes in the phosphorus deposition flux}

The global annual deposition fluxes of TP and DP as computed by TM4-ECPL for the three main simulations (PAST, PRESENT, FUTURE) are provided in Table 4. For the PAST simulation, the model calculates a global TP deposition flux (Table 4) that is about $3 \%$ lower than the present-day flux. Significant increases in TP deposition fluxes since the PAST have been calculated over Indonesia and southeastern Asia (Fig. 6c), as a result of the present high anthropogenic emissions over China. As for the FUTURE simulation, TP deposition is projected to decrease globally by $2.5 \%$ compared to present day (Table 4) with a maximum decrease (up to $40 \%$ ) due to emission control measures calculated for Europe, the eastern USA and China.

On a global scale, DP deposition fluxes are also calculated to be lower by about $20 \%$ in the PAST and by about $15 \%$ in the FUTURE simulations compared to the PRESENT one (Table 4). Although these reductions are computed to be relatively low, regional reductions can be stronger (up to $60 \%$; Fig. 6d), especially over highly populated regions (e.g., China, Europe) and downwind of major dust sources (e.g., India and western USA). Indeed, present-day DP emission fluxes from anthropogenic combustion $\left(0.021 \mathrm{Tg}-\mathrm{P} \mathrm{yr}^{-1}\right)$ is calculated to decrease by about $80 \%$ on a global scale both for the PAST and FUTURE simulations (Table 1). According to our calculations, however, present-day DP biomass burning emissions have increased by about $28 \%$ from PAST and are expected to further increase by about $22 \%$ in the FUTURE simulation. When accounting for both DP anthropogenic combustion and biomass burning emissions, an approximately 3 -fold increase is computed from the PAST to PRESENT but a decrease to half is expected for the FUTURE, thus contributing significantly to the DP atmospheric deposition changes. Hence, DP deposition fluxes are projected to decrease over the midlatitudes of the $\mathrm{NH}$ where human activities dominate (Fig. 6f), with the largest changes up to $60 \%$ over China due to the expected air-quality measures, while smaller changes are computed over India due to the expected increase in its population. Note again that our simulations neglect any changes in dust and PBAP emissions that have occurred in the past or are expected to take place in the future. Therefore, the changes in bioavailable P (BP) deposition fluxes shown in Table 4 are driven by changes in the anthropogenic and biomass burning emissions and in the atmospheric oxidants that enhance $\mathrm{P}$ dissolution during atmospheric ageing.

\subsection{Biogeochemical implications of changes in bioavailable phosphorus deposition}

The contribution of dust to the bioavailable $\mathrm{P}$ deposition flux into the ocean maximizes in the outflow from desert regions, mainly in the North Hemisphere tropics and midlatitudes (Fig. S8a-d). However, according to our simulations, DOP is an important fraction of bioavailable $\mathrm{P}$, mainly over continental regions. Table 4 also presents the sum of the DP and the insoluble PBAP deposition, reported as BP, which is considered to be readily bioavailable for marine ecosystems since it is biological material. Figure S8e-h depict the seasonal variability of the PBAP deposition flux computed by our model for the PRESENT simulation. It is remarkable that our simulations suggest that bioaerosols are a major contributor to the BP deposition fluxes; on an annual basis, PBAPs contribute about $25 \%$ to the global BP deposition fluxes over the oceans (about $33 \%$ on a global scale), but regionally more than $50 \%$ (Fig. 7b) in the outflow of South America over the equatorial Pacific and in the outflow of central Africa over the southern tropical Atlantic. This finding clearly shows that biological material is a major atmospheric carrier of bioavailable $\mathrm{P}$ to the global ocean (Fig. 7b) and implies a potentially important impact of terrestrial sources on marine ecosystems. Note that, as mentioned in Sect. 2, PBAPs from insect fragments and plant debris are neglected in the present study; thus, their contribution to the bioavailable $\mathrm{P}$ deposition mainly over land might be underestimated here. However, large uncertainties are associated with this innovative finding, since the estimates of the global source of PBAPs vary by more than an order of magnitude; their size distributions and their mass density are uncertain, and the $\mathrm{P}$ content in these aerosols is also highly variable, spanning 2 orders of magnitude (e.g., the Supplement of Kanakidou et al., 2012 and references therein). All these parameters have to be studied by targeted experiments to improve knowledge of their contribution to the atmospheric $\mathrm{P}$ cycle. Our results also indicate that primary anthropogenic emissions of DP, as well as anthropogenically driven atmospheric acidity, increased the DP supply to the global ocean since the preindustrial period, thus providing an important externalto-the-ocean source of nutrients for the marine ecosystem. They also show that the $\mathrm{P}$ solubilization from dust aerosol during atmospheric transport and mixing with acidic pollutants is important for DP deposition and deserves further kinetic studies to improve parameterization of the solubilization kinetics of various P-containing minerals as a function of acidity and temperature. These results may be particularly important for ecosystems like the east Mediterranean where phytoplankton growth is limited by $\mathrm{P}$ availability.

It is also noteworthy that the bioavailable $\mathrm{P}$ deposition flux from bioaerosols maximizes in summer (Fig. S8e-h) when ocean stratification is also the strongest, thus leading to the highest impact of atmospheric deposition to the marine ecosystems (Christodoulaki et al., 2013). This flux needs 
to be taken into account to evaluate the atmospheric DP deposition impact on marine ecosystems. The computed atmospheric deposition of BP over the global ocean of $0.17 \mathrm{Tg}$ $\mathrm{P} \mathrm{yr}^{-1}$ (Table 4) represents about $15 \%$ of the global riverine flux to the ocean of $0.99 \mathrm{Tg}^{-} \mathrm{P} \mathrm{yr}^{-1}$ (Meybeck, 1982). However, while riverine inputs affect mainly the coastal regions, atmospheric deposition is a source of nutrients for the open sea (e.g., Okin et al., 2011).

\section{Conclusions}

In this study, the global atmospheric cycle of phosphorus has been simulated with the state-of-the-art atmospheric chemistry transport global model TM4-ECPL. The novel aspect of this study is the simultaneous consideration of primary TP and DP emissions accounting for both inorganic and organic $\mathrm{P}$ and of the atmospheric processing of P. Accounting for a DP (both inorganic and organic) primary source of $0.272 \mathrm{Tg}-\mathrm{P} \mathrm{yr}^{-1}$ together with a $\mathrm{PO}_{4}$ acid-solubilization flux of $0.144 \mathrm{Tg}-\mathrm{P} \mathrm{yr}^{-1}$ and a DOP ageing flux of $0.033 \mathrm{Tg}-$ $\mathrm{P} \mathrm{yr}^{-1}$, result overall in a present-day atmospheric DP burden of $0.003 \mathrm{Tg}-\mathrm{P}$ and a global DP annual deposition flux of 0.455 , of which $0.169 \mathrm{Tg}-\mathrm{P} \mathrm{yr}^{-1}$ is deposited over the oceans. $\mathrm{P}$ solubility in deposited aerosols is calculated to vary spatially with minima over the dust sources $(<10 \%)$ and maxima over the remote ocean (up to $90 \%$ ).

Sensitivity simulations show that increases in anthropogenic and biomass burning emissions since preindustrial times resulted in both enhanced DP combustion primary emissions and $\mathrm{P}$ dissolution occurring under a more acidic environment. Air-quality regulations, however, are projected to decrease anthropogenic emissions, mitigate oxidant levels and limit future atmospheric acidity. Focusing on oceanic regions, atmospheric composition change over the last 150 years is calculated to have increased the DP deposition to the ocean by about $30 \%$ (i.e., 0.132 in preindustrial times against $0.169 \mathrm{Tg}-\mathrm{P} \mathrm{yr}^{-1}$ nowadays). Projection based on future combustion emissions drives the model to a $30 \%$ reduction in mineral $\mathrm{P}$ dissolution flux (0.100 in the future compared to $0.144 \mathrm{Tg}^{-\mathrm{P} \mathrm{yr}^{-1}}$ in the present day) and taking into account an $80 \%$ reduction of the anthropogenic DP emissions, the model calculates an oceanic DP deposition flux of $0.142 \mathrm{Tg}^{-\mathrm{P} \mathrm{yr}^{-1}}$ that is about $16 \%$ lower than in the present day. Our results further indicate a significant contribution to the calculated DP deposition fluxes of DIP up to $90 \%$ over the northern tropical Atlantic, Pacific and Southern oceans, as well as a DOP contribution higher than $50 \%$ over the equatorial oceanic regions.

The contribution of PBAP deposition to the total bioavailable $\mathrm{P}$ to the marine environment is found to exceed $50 \%$ regionally, indicating the existence of potentially important interactions between the terrestrial and the marine biospheres. Therefore, our results provide new insights to the atmospheric $\mathrm{P}$ cycle by demonstrating that PBAPs are as impor- tant carriers of bioavailable $\mathrm{P}$ as dust aerosol, which was up to now considered as the only large source of DP external to the open ocean.

Although the present global modeling study is based on the current understanding of the processes that drive the atmospheric cycle of $\mathrm{P}$, comparison of model results to observations showed that the model underestimates the data by at least $60 \%$. Improvements, thus, require reduction in the large uncertainties that still exist with regard to the primary TP and DP emissions from anthropogenic and natural sources and the adopted kinetic parameters of mineral-P dissolution and organic aerosol-P ageing and their response to the changes in atmospheric acidity. Finally, in view of the importance of $\mathrm{P}$ as a nutrient for marine and terrestrial ecosystems in terms of carbon storage and nitrogen fixation, the calculated changes in $\mathrm{P}$ deposition due to projected air-quality changes indicate the necessity to account for feedbacks between atmospheric chemistry, climate and biogeochemical cycles.

\section{Data availability}

TP, DIP and DOP deposition data are available upon request to mariak@uoc.gr.

\section{The Supplement related to this article is available online at doi:10.5194/bg-13-6519-2016-supplement.}

Acknowledgements. This research has been co-financed by the European Union (European Social Fund - ESF) and Greek national funds through the Operational Program "Education and Lifelong Learning" of the National Strategic Reference Framework (NSRF) - Research Funding Program: ARISTEIA - PANOPLY (Pollution Alters Natural Aerosol Composition: implications for Ocean Productivity, cLimate and air qualitY) grant. Stelios Myriokefalitakis acknowledges the European FP7 collaborative project BACCHUS (Impact of Biogenic versus Anthropogenic emissions on Clouds and Climate: towards a Holistic UnderStanding) for financial support. The authors thank T. van Noije for dust emission module availability; R. Wang for providing anthropogenic and natural combustion P emission data; P. Nicolaou, A. Mitsotaki, C. Theodosi, P. Zarbas and G. Kouvarakis for the observations in the Mediterranean; and R. Vet for providing P deposition data. The authors thank two anonymous referees for constructive comments and S. Bikkina for interactive comments on the manuscript. This is a contibution to GESAMP WG 38.

Edited by: M. Sarin

Reviewed by: two anonymous referees 


\section{References}

Anderson, L. D., Faul, K. L., and Paytan, A.: Phosphorus associations in aerosols: What can they tell us about $\mathrm{P}$ bioavailability?, Mar. Chem., 120, 44-56, doi:10.1016/j.marchem.2009.04.008, 2010.

Andres, R. J. and Kasgnoc, A. D.: A time-averaged inventory of subaerial volcanic sulfur emissions, J. Geophys. Res., 103, 25251, doi:10.1029/98JD02091, 1998.

Ariya, P. A., Sun, J., Eltouny, N. A., Hudson, E. D., Hayes, C. T., and Kos, G.: Physical and chemical characterization of bioaerosols - Implications for nucleation processes, Int. Rev. Phys. Chem., 28, 1-32, doi:10.1080/01442350802597438, 2009.

Baker, A. R., French, M., and Linge, K. L.: Trends in aerosol nutrient solubility along a west-east transect of the Saharan dust plume, Geophys. Res. Lett., 33, L07805, doi:10.1029/2005GL024764, 2006a.

Baker, A. R., Jickells, T. D., Witt, M., and Linge, K. L.: Trends in the solubility of iron, aluminium, manganese and phosphorus in aerosol collected over the Atlantic Ocean, Mar. Chem., 98, 4358, doi:10.1016/j.marchem.2005.06.004, 2006b.

Baker, A. R., Lesworth, T., Adams, C., Jickells, T. D., and Ganzeveld, L.: Estimation of atmospheric nutrient inputs to the Atlantic Ocean from $50^{\circ} \mathrm{N}$ to $50^{\circ} \mathrm{S}$ based on large-scale field sampling: Fixed nitrogen and dry deposition of phosphorus, Global Biogeochem. Cy., 24, GB3006, doi:10.1029/2009GB003634, 2010.

Bauer, H., Schueller, E., Weinke, G., Berger, A., Hitzenberger, R., Marr, I. L., and Puxbaum, H.: Significant contributions of fungal spores to the organic carbon and to the aerosol mass balance of the urban atmospheric aerosol, Atmos. Environ., 42, 5542-5549, doi:10.1016/j.atmosenv.2008.03.019, 2008.

Bengtsson, Å., Lindegren, M., Sjöberg, S., and Persson, P.: Dissolution, adsorption and phase transformation in the fluorapatite-goethite system, Appl. Geochem., 22, 2016-2028, doi:10.1016/j.apgeochem.2007.05.001, 2007.

Bengtsson, Å., Shchukarev, A., Persson, P., and Sjöberg, S.: A solubility and surface complexation study of a non-stoichiometric hydroxyapatite, Geochim. Cosmochim. Ac., 73, 257-267, doi:10.1016/j.gca.2008.09.034, 2009.

Benitez-Nelson, C. R.: The biogeochemical cycling of phosphorus in marine systems, Earth Sci. Rev., 51, 109-135, doi:10.1016/S0012-8252(00)00018-0, 2000.

Bjórkman, K. and Karl, D.: Bioavailability of inorganic and organic phosphorus compounds to natural assemblages of microorganisms m Hawaiian coastal waters, Mar. Ecol.-Prog. Ser., 111, 265273, doi:10.3354/meps111265, 1994.

Björkman, K. M. and Karl, D. M.: Bioavailability of dissolved organic phosphorus in the euphotic zone at Station ALOHA, North Pacific Subtropical Gyre, Limnol. Oceanogr., 48, 1049-1057, doi:10.4319/lo.2003.48.3.1049, 2003.

Bougiatioti, A., Nikolaou, P., Stavroulas, I., Kouvarakis, G., Weber, R., Nenes, A., Kanakidou, M., and Mihalopoulos, N.: Particle water and $\mathrm{pH}$ in the eastern Mediterranean: source variability and implications for nutrient availability, Atmos. Chem. Phys., 16, 4579-4591, doi:10.5194/acp-16-4579-2016, 2016.

Brahney, J., Mahowald, N., Ward, D. S., Ballantyne, A. P., and Neff, J. C.: Is atmospheric phosphorus pollution altering global alpine Lake stoichiometry?, Global Biogeochem. Cy., 29, 1369-1383, doi:10.1002/2015GB005137, 2015.
Burrows, S. M., Elbert, W., Lawrence, M. G., and Pöschl, U.: Bacteria in the global atmosphere - Part 1: Review and synthesis of literature data for different ecosystems, Atmos. Chem. Phys., 9, 9263-9280, doi:10.5194/acp-9-9263-2009, 2009a.

Burrows, S. M., Butler, T., Jöckel, P., Tost, H., Kerkweg, A., Pöschl, U., and Lawrence, M. G.: Bacteria in the global atmosphere - Part 2: Modeling of emissions and transport between different ecosystems, Atmos. Chem. Phys., 9, 9281-9297, doi:10.5194/acp-9-9281-2009, 2009 b.

Cama, J., Ayora, C., and Lasaga, A. C.: The deviation-fromequilibrium effect on dissolution rate and on apparent variations in activation energy, Geochim. Cosmochim. Ac., 63, 2481-2486, doi:10.1016/S0016-7037(99)00144-1, 1999.

Christodoulaki, S., Petihakis, G., Kanakidou, M., Mihalopoulos, N., Tsiaras, K., and Triantafyllou, G.: Atmospheric deposition in the Eastern Mediterranean. A driving force for ecosystem dynamics, J. Mar. Syst., 109-110, 78-93, doi:10.1016/j.jmarsys.2012.07.007, 2013.

Christoffersen, J. and Christoffersen, M. R.: Kinetics of dissolution of calcium hydroxyapatite, J. Cryst. Growth, 53, 42-54, doi:10.1016/0022-0248(81)90054-3, 1981.

Conkright, M. E., Boyer, T. P., and Levitus, S.: World Ocean Atlas: 1994 Nutrients, 1994.

Cook, A. M., Daughton, C. G., and Alexander, M.: Phosphoruscontaining pesticide breakdown products: quantitative utilization as phosphorus sources by bacteria, Appl. Environ. Microbiol., 36, 668-72, 1978.

Daskalakis, N., Myriokefalitakis, S., and Kanakidou, M.: Sensitivity of tropospheric loads and lifetimes of short lived pollutants to fire emissions, Atmos. Chem. Phys., 15, 3543-3563, doi:10.5194/acp-15-3543-2015, 2015.

Dee, D. P., Uppala, S. M., Simmons, A. J., Berrisford, P., Poli, P., Kobayashi, S., Andrae, U., Balmaseda, M. A., Balsamo, G., Bauer, P., Bechtold, P., Beljaars, A. C. M., van de Berg, L., Bidlot, J., Bormann, N., Delsol, C., Dragani, R., Fuentes, M., Geer, A. J., Haimberger, L., Healy, S. B., Hersbach, H., Hølm, E. V., Isaksen, L., Kællberg, P., Köhler, M., Matricardi, M., Mcnally, A. P., Monge-Sanz, B. M., Morcrette, J. J., Park, B. K., Peubey, C., de Rosnay, P., Tavolato, C., Thépaut, J. N., and Vitart, F.: The ERA-Interim reanalysis: Configuration and performance of the data assimilation system, Q. J. Roy. Meteorol. Soc., 137, 553597, doi:10.1002/qj.828, 2011.

Dentener, F., Kinne, S., Bond, T., Boucher, O., Cofala, J., Generoso, S., Ginoux, P., Gong, S., Hoelzemann, J. J., Ito, A., Marelli, L., Penner, J. E., Putaud, J.-P., Textor, C., Schulz, M., van der Werf, G. R., and Wilson, J.: Emissions of primary aerosol and precursor gases in the years 2000 and 1750 prescribed data-sets for AeroCom, Atmos. Chem. Phys., 6, 4321-4344, doi:10.5194/acp-64321-2006, 2006.

Després, V. R., Alex Huffman, J., Burrows, S. M., Hoose, C., Safatov, A. S., Buryak, G., Fröhlich-Nowoisky, J., Elbert, W., Andreae, M. O., Pöschl, U., and Jaenicke, R.: Primary biological aerosol particles in the atmosphere: a review, Tellus B, 64, 15598 , doi:10.3402/tellusb.v64i0.15598, 2012.

Deutsch, C., Sarmiento, J. L., Sigman, D. M., Gruber, N., and Dunne, J. P.: Spatial coupling of nitrogen inputs and losses in the ocean, Nature, 445, 163-167, doi:10.1038/nature05392, 2007.

Du, E., de Vries, W., Han, W., Liu, X., Yan, Z., and Jiang, Y.: Imbalanced phosphorus and nitrogen deposition in China's forests, 
Atmos. Chem. Phys., 16, 8571-8579, doi:10.5194/acp-16-85712016, 2016.

Duce, R. A., LaRoche, J., Altieri, K., Arrigo, K. R., Baker, A. ., Capone, D. G., Cornell, S., Dentener, F., Galloway, J., Ganeshram, R. S., Geider, R. J., Jickells, T., Kuypers, M. M., Langlois, R., Liss, P. S., Liu, S. M., Middelburg, J. J., Moore, C. M., Nickovic, S., Oschlies, A., Pedersen, T., Prospero, J., Schlitzer, R., Seitzinger, S., Sorensen, L. L., Uematsu, M., Ulloa, O., Voss, M., Ward, B., and Zamora, L.: Impacts of atmospheric anthropogenic nitrogen on the open ocean, Science, 320, 893-897, doi:10.1126/science.1150369, 2008.

Eckhardt, S., Quennehen, B., Olivié, D. J. L., Berntsen, T. K., Cherian, R., Christensen, J. H., Collins, W., Crepinsek, S., Daskalakis, N., Flanner, M., Herber, A., Heyes, C., Hodnebrog, Ø., Huang, L., Kanakidou, M., Klimont, Z., Langner, J., Law, K. S., Lund, M. T., Mahmood, R., Massling, A., Myriokefalitakis, S., Nielsen, I. E., Nøjgaard, J. K., Quaas, J., Quinn, P. K., Raut, J.-C., Rumbold, S. T., Schulz, M., Sharma, S., Skeie, R. B., Skov, H., Uttal, T., von Salzen, K., and Stohl, A.: Current model capabilities for simulating black carbon and sulfate concentrations in the Arctic atmosphere: a multi-model evaluation using a comprehensive measurement data set, Atmos. Chem. Phys., 15, 9413-9433, doi:10.5194/acp-15-9413-2015, 2015.

Elser, J. J., Bracken, M. E. S., Cleland, E. E., Gruner, D. S., Harpole, W. S., Hillebrand, H., Ngai, J. T., Seabloom, E. W., Shurin, J. B., and Smith, J. E.: Global analysis of nitrogen and phosphorus limitation of primary producers in freshwater, marine and terrestrial ecosystems, Ecol. Lett., 10, 1135-1142, doi:10.1111/j.14610248.2007.01113.x, 2007.

Fountoukis, C. and Nenes, A.: ISORROPIA II: a computationally efficient thermodynamic equilibrium model for $\mathrm{K}^{+}-\mathrm{Ca}^{2+}-$ $\mathrm{Mg}^{2+}-\mathrm{NH}_{4}^{+}-\mathrm{Na}^{+}-\mathrm{SO}_{4}^{2}-\mathrm{NO}_{3}-\mathrm{Cl}-\mathrm{H}_{2}$ aerosols, Atmos. Chem. Phys., 7, 4639-4659, doi:10.5194/acp-7-4639-2007, 2007.

Gerber, H. E.: Relative Humidity Parameterazion of the Navy Aerosol Model (NAM), 1985.

Ginoux, P., Prospero, J. M., Gill, T. E., Hsu, N. C., and Zhao, M.: Global-scale attribution of anthropogenic and natural dust sources and their emission rates based on MODIS Deep Blue aerosol products, Rev. Geophys., 50, RG3005, doi:10.1029/2012RG000388, 2012.

Graham, W. F. and Duce, R. A.: Atmospheric pathways of the phosphorus cycle, Geochim. Cosmochim. Ac., 43, 1195-1208, doi:10.1016/0016-7037(79)90112-1, 1979.

Graham, W. F. and Duce, R. A.: The atmospheric transport of phosphorus to the western North Atlantic, Atmos. Environ., 16, 10891097, doi:10.1016/0004-6981(82)90198-6, 1982.

Graham, W. F., Piotrowicz, S. R., and Duce, R. A.: The sea as a source of atmospheric phosphorus, Mar. Chem., 7, 325-342, doi:10.1016/0304-4203(79)90019-7, 1979.

Guidry, M. W. and Mackenzie, F. T.: Experimental study of igneous and sedimentary apatite dissolution, Geochim. Cosmochim. Ac., 67, 2949-2963, doi:10.1016/S0016-7037(03)00265-5, 2003.

Heald, C. L. and Spracklen, D. V.: Atmospheric budget of primary biological aerosol particles from fungal spores, Geophys. Res. Lett., 36, L09806, doi:10.1029/2009GL037493, 2009.

Henson, S. A., Painter, S. C., Penny Holliday, N., Stinchcombe, M. C., and Giering, S. L. C.: Unusual subpolar North Atlantic phytoplankton bloom in 2010: Volcanic fertilization or North At- lantic Oscillation?, J. Geophys. Res. Ocean., 118, 4771-4780, doi:10.1002/jgrc.20363, 2013.

Herut, B., Krom, M. D., Pan, G., and Mortimer, R.: Atmospheric input of nitrogen and phosphorus to the Southeast Mediterranean: Sources, fluxes, and possible impact, Limnol. Oceanogr., 44, 1683-1692, doi:10.4319/lo.1999.44.7.1683, 1999.

Hoose, C., Kristjánsson, J. E., and Burrows, S. M.: How important is biological ice nucleation in clouds on a global scale?, Environ. Res. Lett., 5, 024009, doi:10.1088/1748-9326/5/2/024009, 2010.

Hummel, M., Hoose, C., Gallagher, M., Healy, D. A., Huffman, J. A., O'Connor, D., Pöschl, U., Pöhlker, C., Robinson, N. H., Schnaiter, M., Sodeau, J. R., Stengel, M., Toprak, E., and Vogel, H.: Regional-scale simulations of fungal spore aerosols using an emission parameterization adapted to local measurements of fluorescent biological aerosol particles, Atmos. Chem. Phys., 15, 6127-6146, doi:10.5194/acp-15-6127-2015, 2015.

Jacobson, M. Z. and Streets, D. G.: Influence of future anthropogenic emissions on climate, natural emissions, and air quality, J. Geophys. Res., 114, D08118, doi:10.1029/2008JD011476, 2009.

Jickells, T. D., An, Z. S., Andersen, K. K., Baker, A. R., Bergametti, G., Brooks, N., Cao, J. J., Boyd, P. W., Duce, R. A., Hunter, K. A., Kawahata, H., Kubilay, N., laRoche, J., Liss, P. S., Mahowald, N., Prospero, J. M., Ridgwell, A. J., Tegen, I., and Torres, R.: Global Iron Connections Between Desert Dust, Ocean Biogeochemistry, and Climate, Science, 308, 6771, doi:10.1126/science.1105959, 2005.

Kanakidou, M., Mihalopoulos, N., Kindap, T., Im, U., Vrekoussis, M., Gerasopoulos, E., Dermitzaki, E., Unal, A., Koçak, M., Markakis, K., Melas, D., Kouvarakis, G., Youssef, A. F., Richter, A., Hatzianastassiou, N., Hilboll, A., Ebojie, F., Wittrock, F., von Savigny, C., Burrows, J. P., Ladstaetter-Weissenmayer, A., and Moubasher, H.: Megacities as hot spots of air pollution in the East Mediterranean, Atmos. Environ., 45, 1223-1235, doi:10.1016/j.atmosenv.2010.11.048, 2011.

Kanakidou, M., Duce, R. A., Prospero, J. M., Baker, A. R., BenitezNelson, C., Dentener, F. J., Hunter, K. A., Liss, P. S., Mahowald, N., Okin, G. S., Sarin, M., Tsigaridis, K., Uematsu, M., Zamora, L. M., and Zhu, T.: Atmospheric fluxes of organic N and $\mathrm{P}$ to the global ocean, Global Biogeochem. Cy., 26, GB3026/1-12, doi:10.1029/2011GB004277, 2012.

Kanakidou, M., Myriokefalitakis, S., Daskalakis, N., Fanourgakis, G., Nenes, A., Baker, A. R., Tsigaridis, K., and Mihalopoulos, N.: Past, Present and Future Atmospheric Nitrogen Deposition, J. Atmos. Sci., 73, 2039-2047, doi:10.1175/JAS-D-15-0278.1, 2016.

Koulouri, E., Saarikoski, S., Theodosi, C., Markaki, Z., Gerasopoulos, E., Kouvarakis, G., Makela, T., Hillamo, R., and Mihalopoulos, N.: Chemical composition and sources of fine and coarse aerosol particles in the Eastern Mediterranean, Atmos. Environ., 42, 6542-6550, doi:10.1016/j.atmosenv.2008.04.010, 2008.

Krom, M. D., Woodward, E. M. S., Herut, B., Kress, N., Carbo, P., Mantoura, R. F. C., Spyres, G., Thingsted, T. F., Wassmann, P., Wexels-Riser, C., Kitidis, V., Law, C., and Zodiatis, G.: Nutrient cycling in the south east Levantine basin of the eastern Mediterranean: Results from a phosphorus starved system, Deep. Res. Pt. II, 52, 2879-2896, doi:10.1016/j.dsr2.2005.08.009, 2005.

Lamarque, J.-F., Shindell, D. T., Josse, B., Young, P. J., Cionni, I., Eyring, V., Bergmann, D., Cameron-Smith, P., Collins, W. J., Do- 
herty, R., Dalsoren, S., Faluvegi, G., Folberth, G., Ghan, S. J., Horowitz, L. W., Lee, Y. H., MacKenzie, I. A., Nagashima, T., Naik, V., Plummer, D., Righi, M., Rumbold, S. T., Schulz, M., Skeie, R. B., Stevenson, D. S., Strode, S., Sudo, K., Szopa, S., Voulgarakis, A., and Zeng, G.: The Atmospheric Chemistry and Climate Model Intercomparison Project (ACCMIP): overview and description of models, simulations and climate diagnostics, Geosci. Model Dev., 6, 179-206, doi:10.5194/gmd-6-179-2013, 2013.

Lasaga, A. C., Soler, J. M., Ganor, J., Burch, T. E., and Nagy, K. L.: Chemical weathering rate laws and global geochemical cycles, Geochim. Cosmochim. Ac., 58, 2361-2386, doi:10.1016/00167037(94)90016-7, 1994.

Lawrence, C. R. and Neff, J. C.: The contemporary physical and chemical flux of aeolian dust: A synthesis of direct measurements of dust deposition, Chem. Geol., 267, 46-63, doi:10.1016/j.chemgeo.2009.02.005, 2009.

Levitus, S., Burgett, R., and Boyer, T. P.: World Ocean Atlas 1994 Volume 3, Nutrients, World Ocean Atlas, 3, 1994.

Maher, W. and Woo, L.: Procedures for the storage and digestion of natural waters for the determination of filterable reactive phosphorus, total filterable phosphorus and total phosphorus, Anal. Chim. Ac., 375, 5-47, doi:10.1016/S0003-2670(98)002748, 1998.

Mahowald, N., Jickells, T. D., Baker, A. R., Artaxo, P., BenitezNelson, C. R., Bergametti, G., Bond, T. C., Chen, Y., Cohen, D. D., Herut, B., Kubilay, N., Losno, R., Luo, C., Maenhaut, W., McGee, K. A., Okin, G. S., Siefert, R. L., and Tsukuda, S.: Global distribution of atmospheric phosphorus sources, concentrations and deposition rates, and anthropogenic impacts, Global Biogeochem. Cy., 22, 1-19, doi:10.1029/2008GB003240, 2008.

Mahowald, N. M., Artaxo, P., Baker, A. R., Jickells, T. D., Okin, G. S., Randerson, J. T., and Townsend, A. R.: Impacts of biomass burning emissions and land use change on Amazonian atmospheric phosphorus cycling and deposition, Global Biogeochem. Cy., 19, GB4030, doi:10.1029/2005GB002541, 2005.

Mahowald, N. M., Kloster, S., Engelstaedter, S., Moore, J. K., Mukhopadhyay, S., McConnell, J. R., Albani, S., Doney, S. C., Bhattacharya, A., Curran, M. A. J., Flanner, M. G., Hoffman, F. M., Lawrence, D. M., Lindsay, K., Mayewski, P. A., Neff, J., Rothenberg, D., Thomas, E., Thornton, P. E., and Zender, C. S.: Observed 20th century desert dust variability: impact on climate and biogeochemistry, Atmos. Chem. Phys., 10, 10875-10893, doi:10.5194/acp-10-10875-2010, 2010.

Markaki, Z., Oikonomou, K., Kocak, M., Kouvarakis, G., Chaniotaki, A., Kubilay, N., and Mihalopoulos, N.: Atmospheric deposition of inorganic phosphorus in the Levatine Basin, eastern Mediterranean: spatial and temporal variability and its role in seawater productivity, Limnol. Oceanogr., 48, 1557-1568, 2003.

Markaki, Z., Loye-Pilot, M. D., Violaki, K., Benyahya, L., and Mihalopoulos, N.: Variability of atmospheric deposition of dissolved nitrogen and phosphorus in the Mediterranean and possible link to the anomalous seawater N / P ratio, Mar. Chem., 120, 187-194, doi:10.1016/j.marchem.2008.10.005, 2010.

Martino, M., Hamilton, D., Baker, A. R., Jickells, T. D., Bromley, T., Nojiri, Y., Quack, B., and Boyd, P. W.: Western Pacific atmospheric nutrient deposition fluxes, their impact on surface ocean productivity, Global Biogeochem. Cy., 28, 712-728, doi:10.1002/2013GB004794, 2014.
Meybeck, M.: Carbon, Nitrogen, and Phosophorous Transport by World Rivers, Am. J. Sci., 282, 401-450, doi:10.2475/ajs.282.4.401, 1982.

Moore, C. M., Mills, M. M., Arrigo, K. R., Berman-Frank, I., Bopp, L., Boyd, P. W., Galbraith, E. D., Geider, R. J., Guieu, C., Jaccard, S. L., Jickells, T. D., La Roche, J., Lenton, T. M., Mahowald, N. M., Maranon, E., Marinov, I., Moore, J. K., Nakatsuka, T., Oschlies, A., Saito, M. A., Thingstad, T. F., Tsuda, A., and Ulloa, O.: Processes and patterns of oceanic nutrient limitation, Nat. Geosci., 6, 701-710, doi:10.1038/ngeo1765, 2013.

Moutin, T., Karl, D. M., Duhamel, S., Rimmelin, P., Raimbault, P., Van Mooy, B. A. S., and Claustre, H.: Phosphate availability and the ultimate control of new nitrogen input by nitrogen fixation in the tropical Pacific Ocean, Biogeosciences, 5, 95-109, doi:10.5194/bg-5-95-2008, 2008.

Myriokefalitakis, S., Vignati, E., Tsigaridis, K., Papadimas, C., Sciare, J., Mihalopoulos, N., Facchini, M. C., Rinaldi, M., Dentener, F. J., Ceburnis, D., Hatzianastasiou, N., O’Dowd, C. D., van Weele, M. and Kanakidou, M.: Global Modeling of the Oceanic Source of Organic, Aerosols, Adv. Meteorol., 2010, 116, doi:10.1155/2010/939171, 2010.

Myriokefalitakis, S., Tsigaridis, K., Mihalopoulos, N., Sciare, J., Nenes, A., Kawamura, K., Segers, A., and Kanakidou, M.: Incloud oxalate formation in the global troposphere: a 3-D modeling study, Atmos. Chem. Phys., 11, 5761-5782, doi:10.5194/acp11-5761-2011, 2011.

Myriokefalitakis, S., Daskalakis, N., Mihalopoulos, N., Baker, A. R., Nenes, A., and Kanakidou, M.: Changes in dissolved iron deposition to the oceans driven by human activity: a 3-D global modelling study, Biogeosciences, 12, 3973-3992, doi:10.5194/bg-12-3973-2015, 2015.

Myriokefalitakis, S, Daskalakis, N., Fanourgakis, G. S., Voulgarakis, A., Krol, M. C., Aan de Brugh, J. M. J., and Kanakidou, M.: Ozone and carbon monoxide budgets over the Eastern Mediterranean, Sci. Total Environ., 563-564, 40-52, doi:10.1016/j.scitotenv.2016.04.061, 2016.

Neff, J. C., Reynolds, R. L., Munson, S. M., Fernandez, D., and Belnap, J.: The role of dust storms in total atmospheric particle concentrations at two sites in the western US, J. Geophys. Res.Atmos., 118, 11201-11212, doi:10.1002/jgrd.50855, 2013.

Nenes, A., Krom, M. D., Mihalopoulos, N., Van Cappellen, P., Shi, Z., Bougiatioti, A., Zarmpas, P., and Herut, B.: Atmospheric acidification of mineral aerosols: a source of bioavailable phosphorus for the oceans, Atmos. Chem. Phys., 11, 6265-6272, doi:10.5194/acp-11-6265-2011, 2011.

Newman, E. I.: Phosphorus inputs to terrestrial ecosystems, J. Ecol., 83, 713-726, doi:10.2307/2261638, 1995.

Nickovic, S., Vukovic, A., Vujadinovic, M., Djurdjevic, V., and Pejanovic, G.: Technical Note: High-resolution mineralogical database of dust-productive soils for atmospheric dust modeling, Atmos. Chem. Phys., 12, 845-855, doi:10.5194/acp-12-8452012, 2012.

Okin, G. S., Baker, A. R., Tegen, I., Mahowald, N. M., Dentener, F. J., Duce, R. A., Galloway, J. N., Hunter, K., Kanakidou, M., Kubilay, N., Prospero, J. M., Sarin, M., Surapipith, V., Uematsu, M., and Zhu, T.: Impacts of atmospheric nutrient deposition on marine productivity: Roles of nitrogen, phosphorus, and iron, Global Biogeochem. Cy., 25, 1-10, doi:10.1029/2010GB003858, 2011. 
Olgun, N., Duggen, S., Langmann, B., Hort, M., Waythomas, C. F., Hoffmann, L., and Croot, P.: Geochemical evidence of oceanic iron fertilization by the Kasatochi volcanic eruption in 2008 and the potential impacts on Pacific sockeye salmon, Mar. Ecol.Prog. Ser., 488, 81-88, doi:10.3354/meps10403, 2013.

Olson, J.: Major world ecosystem complexes ranked by carbon in live vegetation: A database, Glob. Ecosyst. Database, Version 1, doi:10.3334/CDIAC/lue.ndp017, 1992.

Palandri, J. L. and Kharaka, Y. K.: A compilation of rate parameters of water-mineral interaction kinetics for application to geochemical modeling, Menlo Park, Calif. US Dept. Inter. US Geol. Surv., 64, 2004.

Paytan, A., Cade-Menun, B. J., McLaughlin, K., and Faul, K. L.: Selective phosphorus regeneration of sinking marine particles: evidence from 31P-NMR, Mar. Chem., 82, 55-70, doi:10.1016/S0304-4203(03)00052-5, 2003.

Perlwitz, J. P., Pérez García-Pando, C., and Miller, R. L.: Predicting the mineral composition of dust aerosols - Part 1: Representing key processes, Atmos. Chem. Phys., 15, 11593-11627, doi:10.5194/acp-15-11593-2015, 2015.

Powell, C. F., Baker, A. R., Jickells, T. D., Bange, H. W., Chance, R. J., and Yodle, C.: Estimation of the Atmospheric Flux of Nutrients and Trace Metals to the Eastern Tropical North Atlantic Ocean, J. Atmos. Sci., 72, 4029-4045, doi:10.1175/JAS-D-150011.1, 2015.

Prospero, J. M. and Lamb, P. J.: African droughts and dust transport to the Caribbean: climate change implications, Science, 302, 1024-1027, doi:10.1126/science.1089915, 2003.

Quennehen, B., Raut, J.-C., Law, K. S., Daskalakis, N., Ancellet, G., Clerbaux, C., Kim, S.-W., Lund, M. T., Myhre, G., Olivié, D. J. L., Safieddine, S., Skeie, R. B., Thomas, J. L., Tsyro, S., Bazureau, A., Bellouin, N., Hu, M., Kanakidou, M., Klimont, Z., Kupiainen, K., Myriokefalitakis, S., Quaas, J., Rumbold, S. T., Schulz, M., Cherian, R., Shimizu, A., Wang, J., Yoon, S.-C., and Zhu, T.: Multi-model evaluation of short-lived pollutant distributions over east Asia during summer 2008, Atmos. Chem. Phys., 16, 10765-10792, doi:10.5194/acp-16-10765-2016, 2016.

Schaperdoth, I., Liermann, L. J., and Brantley, S. L.: The Effect of Polymeric Substances on Apatite Reactivity in the Presence of a Freshwater Cyanobacterium, Geomicrobiol. J., 24, 79-91, doi:10.1080/01490450701266548, 2007.

Sesartic, A. and Dallafior, T. N.: Global fungal spore emissions, review and synthesis of literature data, Biogeosciences, 8, 11811192, doi:10.5194/bg-8-1181-2011, 2011.

Smil, V.: Phosphorus in the environment: Natural Flows and Human Interferences, Annu. Rev. Energy Environ., 25, 53-88, doi:10.1146/annurev.energy.25.1.53, 2000.

Somasundaran, P., Amankonah, J. O., and Ananthapadmabhan, K. P.: Mineral-solution equilibria in sparingly soluble mineral systems, Colloid. Surface., 15, 309-333, doi:10.1016/01666622(85)80081-0, 1985.

Srinivas, B. and Sarin, M. M.: Atmospheric pathways of phosphorous to the Bay of Bengal: contribution from anthropogenic sources and mineral dust, Tellus B, 64, 1-12, doi:10.3402/tellusb.v64i0.17174, 2012.

Srinivas, B. and Sarin, M. M.: Atmospheric deposition of N, $\mathrm{P}$ and $\mathrm{Fe}$ to the Northern Indian Ocean: Implications to C- and N-fixation, Sci. Total Environ., 456-457, 104-114, doi:10.1016/j.scitotenv.2013.03.068, 2013.
Srinivas, B. and Sarin, M. M.: Atmospheric deposition of phosphorus to the Northern Indian Ocean, Curr. Sci., 108, 2015.

Stohl, A., Aamaas, B., Amann, M., Baker, L. H., Bellouin, N., Berntsen, T. K., Boucher, O., Cherian, R., Collins, W., Daskalakis, N., Dusinska, M., Eckhardt, S., Fuglestvedt, J. S., Harju, M., Heyes, C., Hodnebrog, Ø., Hao, J., Im, U., Kanakidou, M., Klimont, Z., Kupiainen, K., Law, K. S., Lund, M. T., Maas, R., MacIntosh, C. R., Myhre, G., Myriokefalitakis, S., Olivié, D., Quaas, J., Quennehen, B., Raut, J.-C., Rumbold, S. T., Samset, B. H., Schulz, M., Seland, Ø., Shine, K. P., Skeie, R. B., Wang, S., Yttri, K. E., and Zhu, T.: Evaluating the climate and air quality impacts of short-lived pollutants, Atmos. Chem. Phys., 15, 10529-10566, doi:10.5194/acp-15-10529-2015, 2015.

Tegen, I., Harrison, S. P., Kohfeld, K., Prentice, I. C., Coe, M., and Heimann, M.: Impact of vegetation and preferential source areas on global dust aerosol: Results from a model study, J. Geophys. Res.-Atmos., 107, AAC 14-1-AAC 14-27, doi:10.1029/2001JD000963, 2002.

Tipping, E., Benham, S., Boyle, J. F., Crow, P., Davies, J., Fischer, U., Guyatt, H., Helliwell, R., Jackson-Blake, L., Lawlor, A. J., Monteith, D. T., Rowe, E. C., and Toberman, H.: Atmospheric deposition of phosphorus to land and freshwater, Environ. Sci. Process. Impacts, 16, 1608-1617, doi:10.1039/C3EM00641G, 2014.

Tsigaridis, K. and Kanakidou, M.: Global modelling of secondary organic aerosol in the troposphere: a sensitivity analysis, Atmos. Chem. Phys., 3, 1849-1869, doi:10.5194/acp-3-1849-2003, 2003.

Tsigaridis, K. and Kanakidou, M.: Secondary organic aerosol importance in the future atmosphere, Atmos. Environ., 41, 46824692, doi:10.1016/j.atmosenv.2007.03.045, 2007.

Tsigaridis, K., Krol, M., Dentener, F. J., Balkanski, Y., Lathière, J., Metzger, S., Hauglustaine, D. A., and Kanakidou, M.: Change in global aerosol composition since preindustrial times, Atmos. Chem. Phys., 6, 5143-5162, doi:10.5194/acp-6-5143-2006, 2006.

Tsigaridis, K., Koch, D., and Menon, S.: Uncertainties and importance of sea spray composition on aerosol direct and indirect effects, J. Geophys. Res.-Atmos., 118, 220-235, doi:10.1029/2012JD018165, 2013.

Tsigaridis, K., Daskalakis, N., Kanakidou, M., Adams, P. J., Artaxo, P., Bahadur, R., Balkanski, Y., Bauer, S. E., Bellouin, N., Benedetti, A., Bergman, T., Berntsen, T. K., Beukes, J. P., Bian, H., Carslaw, K. S., Chin, M., Curci, G., Diehl, T., Easter, R. C., Ghan, S. J., Gong, S. L., Hodzic, A., Hoyle, C. R., Iversen, T., Jathar, S., Jimenez, J. L., Kaiser, J. W., Kirkevåg, A., Koch, D., Kokkola, H., Lee, Y. H., Lin, G., Liu, X., Luo, G., Ma, X., Mann, G. W., Mihalopoulos, N., Morcrette, J.-J., Müller, J.-F., Myhre, G., Myriokefalitakis, S., Ng, N. L., O’Donnell, D., Penner, J. E., Pozzoli, L., Pringle, K. J., Russell, L. M., Schulz, M., Sciare, J., Seland, Ø., Shindell, D. T., Sillman, S., Skeie, R. B., Spracklen, D., Stavrakou, T., Steenrod, S. D., Takemura, T., Tiitta, P., Tilmes, S., Tost, H., van Noije, T., van Zyl, P. G., von Salzen, K., Yu, F., Wang, Z., Wang, Z., Zaveri, R. A., Zhang, H., Zhang, K., Zhang, Q., and Zhang, X.: The AeroCom evaluation and intercomparison of organic aerosol in global models, Atmos. Chem. Phys., 14, 10845-10895, doi:10.5194/acp-1410845-2014, 2014. 
Uematsu, M., Toratani, M., Kajino, M., Narita, Y., Senga, Y., and Kimoto, T.: Enhancement of primary productivity in the western North Pacific caused by the eruption of the Miyake-jima Volcano, Geophys. Res. Lett., 31, L06106, doi:10.1029/2003GL018790, 2004.

van Cappellen, P. and Berner, R. A.: Fluorapatite crystal growth from modified seawater solutions, Geochim. Cosmochim. Ac., 55, 1219-1234, doi:10.1016/0016-7037(91)90302-L, 1991.

van Noije, T. P. C., Le Sager, P., Segers, A. J., van Velthoven, P. F. J., Krol, M. C., Hazeleger, W., Williams, A. G., and Chambers, S. D.: Simulation of tropospheric chemistry and aerosols with the climate model EC-Earth, Geosci. Model Dev., 7, 2435-2475, doi:10.5194/gmd-7-2435-2014, 2014.

van Vuuren, D. P., Edmonds, J., Kainuma, M., Riahi, K., Thomson, A., Hibbard, K., Hurtt, G. C., Kram, T., Krey, V., Lamarque, J.-F., Masui, T., Meinshausen, M., Nakicenovic, N., Smith, S. J., and Rose, S. K.: The representative concentration pathways: an overview, Clim. Change, 109, 5-31, doi:10.1007/s10584-0110148-z, 2011.

Vet, R., Artz, R. S., Carou, S., Shaw, M., Ro, C. U., Aas, W., Baker, A., Bowersox, V. C., Dentener, F., Galy-Lacaux, C., Hou, A., Pienaar, J. J., Gillett, R., Forti, M. C., Gromov, S., Hara, H., Khodzher, T., Mahowald, N. M., Nickovic, S., Rao, P. S. P., and Reid, N. W.: A global assessment of precipitation chemistry and deposition of sulfur, nitrogen, sea salt, base cations, organic acids, acidity and pH, and phosphorus, Atmos. Environ., 93, 3100, doi:10.1016/j.atmosenv.2013.10.060, 2014.
Vignati, E., Facchini, M. C., Rinaldi, M., Scannell, C., Ceburnis, D., Sciare, J., Kanakidou, M., Myriokefalitakis, S., Dentener, F., and ODowd, C. D.: Global scale emission and distribution of seaspray aerosol: Sea-salt and organic enrichment, Atmos. Environ., 44, 670-677, doi:10.1016/j.atmosenv.2009.11.013, 2010.

Wang, R., Balkanski, Y., Boucher, O., Ciais, P., Peñuelas, J., and Tao, S.: Significant contribution of combustion-related emissions to the atmospheric phosphorus budget, Nat. Geosci., 8, 48-54, doi:10.1038/ngeo2324, 2014.

Wang, Y. P., Law, R. M., and Pak, B.: A global model of carbon, nitrogen and phosphorus cycles for the terrestrial biosphere, Biogeosciences, 7, 2261-2282, doi:10.5194/bg-7-2261-2010, 2010.

Weber, R. J., Guo, H., Russell, A. G., and Nenes, A.: High aerosol acidity despite declining atmospheric sulfate concentrations over the past 15 years, Nat. Geosci., 9, 282-285, doi:10.1038/NGEO2665, 2016.

Yang, X., Post, W. M., Thornton, P. E., and Jain, A.: The distribution of soil phosphorus for global biogeochemical modeling, Biogeosciences, 10, 2525-2537, doi:10.5194/bg-10-2525-2013, 2013.

Zamora, L. M., Prospero, J. M., Hansell, D. A., and Trapp, J. M.: Atmospheric P deposition to the subtropical North Atlantic: sources, properties, and relationship to $\mathrm{N}$ deposition, J. Geophys. Res.-Atmos., 118, 1546-1562, doi:10.1002/jgrd.50187, 2013. 